\title{
Sistema Composicional Intermarkoviano
}

\author{
Esdras Sarmento Ferreira | Universidade Federal da Paraíba | Brasil \\ Raphael Sousa Santos | Pesquisador independente | Holanda \\ Flávio Fernandes de Lima | Instituto Federal de Pernambuco | Brasil \\ Hugo Tremonte de Carvalho | Universidade Federal do Rio de Janeiro | Brasil \\ Liduino Pitombeira | Universidade Federal do Rio de Janeiro | Brasil
}

\begin{abstract}
Resumo $\mathrm{O}$ presente artigo trata da descrição do Sistema Composicional Intermarkoviano, resultado de uma convergência entre a teoria da intertextualidade e das cadeias de Markov, com o objetivo de estabelecer diretrizes pré-composicionais. Tais diretrizes se originam, no caso específico deste trabalho, das partições texturais rítmicas e dos contornos melódicos de uma obra musical original: o segundo movimento dos Cinco Movimentos para Quarteto de Cordas, Op. 5 de Webern. A operacionalidade do sistema é facilitada através de um aplicativo computacional denominado Markov Model, desenvolvido durante a pesquisa. Como resultado composicional, foi planejada e composta uma nova obra, cujas relaçóes profundas de interdependência textural e contorno melódico se aproximam da obra original.
\end{abstract}

Palavras-chave: Sistemas Composicionais, Cadeias de Markov, Intertextualidade, Teoria dos Contornos, Partições Texturais Rítmicas.

\begin{abstract}
This article deals with the description of the Intermarkovian Compositional System, the result of a convergence between the theory of intertextuality and Markov chains, with the purpose of establishing precompositional guidelines. Such guidelines originate, in the specific case of this work, from rhythmic textural partitions and melodic contours of an original musical work: the second movement of the Five Movements for String Quartet, Op. 5 by Webern. The system's operability is facilitated through a computational application called Markov Model, developed during the research. As a compositional result, a new work was planned and composed, whose deep relationships of textural interdependence and melodic contour are close to the original work.
\end{abstract}

Keywords: Compositional Systems, Markov Chains, Intertextuality, Contour Theory, Rhythmic Textural Partitions. 
FERREIRA, Esdras Sarmento; SANTOS, Raphael Sousa; LIMA, Flávio Fernandes de; CARVALHO, Hugo Tremonte de; PITOMBEIRA, Liduino. Sistema Composicional Intermarkoviano. Revista Vórtex, Curitiba, v.8, n.2, p. 1-46, 2020.

$\mathrm{N}$ os capítulos I a III de sua obra Formalized Music, Iannis Xenakis (1992) introduz a possibilidade de utilizar elementos estocásticos na composição musical, em particular cadeias de Markov (capítulos II e III). Baseados nesse princípio, propomos, neste trabalho, o Sistema Composicional Intermarkoviano, que utiliza cadeias de Markov como forma de definir relações sintáticas pré-composicionais a partir dos contornos melódicos e das partições rítmicas observados no segundo movimento dos Cinco Movimentos para Quarteto de Cordas, Op. 5 de Anton Webern. Assim, nesse sistema, além de princípios markovianos e da teoria da intertextualidade (que juntas originam o nome do próprio sistema), utilizamos concomitantemente a teoria dos contornos (SAMPAIO, 2012) e a análise particional, proposta por Pauxy Gentil-Nunes (2009). Durante a pesquisa, as operações de geração dos repositórios composicionais foram automatizadas com o auxílio de um aplicativo computacional denominado Markov Model elaborado em Java por um dos autores, Raphael Sousa Santos.

Faremos inicialmente uma breve fundamentação dos conceitos de sistema composicional (Seção 1), intertextualidade (Seção 2), contornos (Seção 3), partições texturais rítmicas (Seção 4) e cadeias de Markov (Seção 5). Em seguida, descreveremos o aplicativo, que é o núcleo do sistema composicional (Seção 6) que foi utilizado por um dos autores, Liduino Pitombeira, para o planejamento (Seção 7) e a composição do primeiro movimento (Infinito) de uma obra para corne inglês e trio de cordas, intitulada Plate Two: Érebo, Op.255 (2020).

\section{Sistemas composicionais}

Denomina-se sistema composicional um conjunto de definições generalizadas préestabelecidas que se relacionam aos aspectos léxicos e sintáticos de um trabalho composicional, ou seja, que são intimamente ligadas à geração de materiais e às relaçốes de interconexôes entre esses materiais. Tais materiais são tratados em nível de sistema de forma genérica, isto é, sem particularizações. As definiçốes sistêmicas são manipuladas pelo compositor durante o planejamento composicional, ao conferir-lhes particularizações específicas. Assim, se imaginarmos um léxico que se 
FERREIRA, Esdras Sarmento; SANTOS, Raphael Sousa; LIMA, Flávio Fernandes de; CARVALHO, Hugo Tremonte de; PITOMBEIRA, Liduino. Sistema Composicional Intermarkoviano. Revista Vórtex, Curitiba, v.8, n.2, p. 1-46, 2020.

resume a duas classes de conjuntos que se conectam por movimentos parcimoniosos ${ }^{1}$ entre seus elementos (sintaxe), teremos definido um sistema composicional. Ao planejarmos uma composição com esse sistema, teremos que escolher duas classes de conjuntos e uma maneira de conectá-las que se adeque à condição de movimento parcimonioso estabelecido pelo sistema. Um esboço précomposicional deste processo pode ser observado na Figura 1, onde o primeiro conjunto de classes de notas (4567), cuja forma prima é [0123]², se conecta o segundo conjunto (349A), cuja forma prima é [0167], de tal maneira que três de seus elementos se movem por grau conjunto enquanto um permanece estático (Mi). O efeito secundário desse processo é a geração de diversas outras sonoridades entre os componentes que formam a classe de conjuntos [0123] quando tais componentes se movem parcimoniosamente em direção à classe de conjuntos [0167].

FIGURA 1 - Sistema composicional parcimonioso: o conjunto de classes de notas (4567), cuja forma prima é [0123], se conecta parcimoniosamente ao conjunto de classes de notas (349A), com forma [0167]. Diversas sonoridades se formam durante o processo.

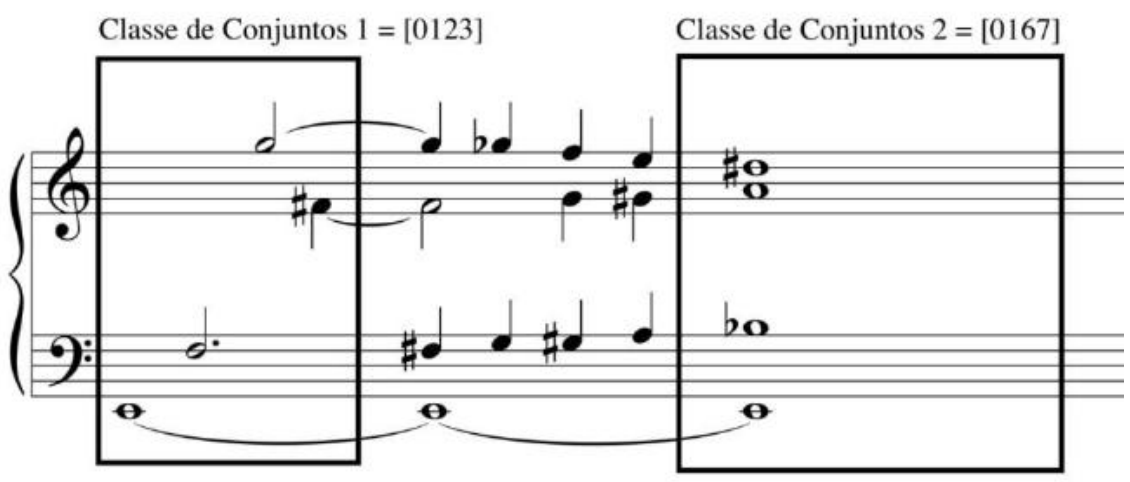

Formalmente, um sistema composicional pode ser definido como "um conjunto de diretrizes, formando um todo coerente, que coordena a utilização e interconexão de parâmetros musicais, com o propósito de produzir obras musicais” (LIMA, 2011, p. 62). Posteriormente, Pitombeira (2015, p.

\footnotetext{
${ }^{1}$ A parcimônia, um conceito introduzido pela Teoria Neorriemanniana, consiste no movimento econômico entre dois acordes. Como afirmam Douthett e Steinbach (1998, p. 243), ainda que a definição de parcimônia esteja ainda evoluindo, as diferentes abordagens têm pelo menos dois fatores em comum: 1) notas comuns são mantidas e 2) as notas remanescentes se movem por um intervalo menor ou igual a um tom inteiro.

${ }^{2}$ Neste trabalho utilizamos a teoria dos conjuntos de classes de notas segundo a metodologia de Rahn-Straus (2013). Assim, representamos formas primas entre colchetes e formas normais entres parênteses. As letras A e B são usadas respectivamente para as classes de notas Sib e Sit. Utilizamos intercambiavelmente os termos classe de altura e classe de nota, que são sinônimos.
} 
FERREIRA, Esdras Sarmento; SANTOS, Raphael Sousa; LIMA, Flávio Fernandes de; CARVALHO, Hugo Tremonte de; PITOMBEIRA, Liduino. Sistema Composicional Intermarkoviano. Revista Vórtex, Curitiba, v.8, n.2, p. 1-46, 2020.

69) atualizou essa definição incluindo materiais em sua totalidade e não só perspectivas paramétricas desses materiais ${ }^{3}$, o que será útil, por exemplo, para a manipulação de intertextos sem transformaçóes. Operacionalmente, um sistema composicional pode ser implementado a partir de 1) um conjunto de definiçóes acerca do funcionamento de determinados parâmetros musicais com a finalidade de produzir materiais e de estabelecer regras de interconexão entre esses materiais; 2) um algoritmo computacional que encapsula diretrizes paramétricas gerando como resultado desde partituras finalizadas até repositórios a serem manipulados pelo compositor; ou 3) tabelas, diagramas e gráficos que guardam informações sobre o comportamento de parâmetros musicais.

Quanto à sua natureza, um sistema composicional pode ser original ou modelado. No primeiro caso, as diretrizes do sistema são elaboradas sem o apoio de estruturas prévias. O exemplo da Figura 1 é um sistema original. No segundo caso, o sistema composicional é um modelo de uma obra musical pré-existente. Trata-se, nesse caso, de um modelo sistêmico ${ }^{4}$, cuja base epistemológica é um tipo de intertextualidade abstrata $^{5}$, no sentido de que apenas relações internas (e não objetos superficiais ${ }^{6}$ ) são intertextualizadas. Tal sistema composicional é hipotético, uma vez que as intenções do compositor da obra modelada não entram necessariamente em sua configuração. Neste trabalho, lidaremos com um sistema modelado, já que suas relações formadoras são oriundas de uma obra musical pré-existente.

Antes que examinemos mais detalhadamente a modelagem sistêmica, é interessante que nos debrucemos inicialmente sobre a noção de modelo. Segundo Mikhail Malt (2000, p. 91), "a noção de modelo abrange um campo semântico complexo, com um espectro muito amplo de significados, que vai de formalismos matemáticos a maquetes e moldes" ${ }^{7}$. Klaus Niemeyer (2007) observa que um

\footnotetext{
${ }^{3}$ Em outras palavras, um sistema composicional aceita como entrada (no caso de sistemas abertos) tanto os materiais em sua integralidade (um trecho melódico com suas alturas, ritmos, articulações etc., por exemplo) como também um parâmetro específico desses materiais (somente suas alturas, por exemplo). No primeiro caso, nos referimos aos sistemas composicionais que desenvolvem operações de colagem e superposição de intertextos, sem alteração em seus conteúdos; no segundo caso, o compositor extrai elementos paramétricos específicos que lhe interessam antes da inserção no sistema. ${ }^{4}$ A modelagem sistêmica trata da proposição de sistemas composicionais hipotéticos partindo da análise de um texto musical (ou de outra natureza) com foco em determinadas perspectivas paramétricas. Para um maior aprofundamento sobre essa teoria ver Pitombeira (2018).

${ }^{5}$ Definida na Seção 2 deste trabalho.

${ }^{6}$ Objetos superficiais são estruturas léxicas perceptíveis de maneira imediata em um texto musical. Esses objetos são associados aos parâmetros altura, dinâmica, ritmo (duração e ponto de ataque) etc.

${ }^{7}$ No original lê-se: "La notion de modèle couvre un champ sémantique complexe, avec un spectre très large de significations, qui va des formalismes mathématiques aux maquettes et aux moules".
} 
FERREIRA, Esdras Sarmento; SANTOS, Raphael Sousa; LIMA, Flávio Fernandes de; CARVALHO, Hugo Tremonte de; PITOMBEIRA, Liduino. Sistema Composicional Intermarkoviano. Revista Vórtex, Curitiba, v.8, n.2, p. 1-46, 2020.

modelo pode ser a representação de um objeto ou estrutura original (modelo perceptual) ou o protótipo para algo que será construído no futuro (modelo antecipatório). Em termos de pesquisa em composição musical, o primeiro tipo de modelo se relaciona com os sistemas composicionais modelados, ou seja, originados através de modelagem sistêmica; o segundo, por sua vez, se relaciona aos sistemas composicionais originais. Em ambos os casos há uma estrutura original que é modelada para gerar uma estrutura virtual: um modelo. A diferença é que nos sistemas modelados a estrutura original está no passado e nos sistemas originais a estrutura está no futuro.

Malt (2000, p.101-102) diferencia quatro tipos de modelo no âmbito musical: [1] Lógico, que é construído a partir de relações lógicas ou abstratas; [2] Analógico, que se baseia em estruturas formalizadas não musicais; [3] Metafórico, que se baseia na linguagem ou outras estruturas extramusicais; e [4] Fórico, que intertextualiza uma estética ou mesmo uma obra. Esses quatro tipos de modelos podem ser construídos originalmente, pela prospecção e planejamento de uma nova obra musical, ou podem surgir como modelo de uma obra pré-existente, através da modelagem sistêmica ${ }^{8}$.

A modelagem sistêmica (Pitombeira, 2018) é metodologicamente operacionalizada em três fases. Na primeira fase, denominada seleção paramétrica, o compositor seleciona, a partir de uma análise prospectiva inicial, o parâmetro (ou os parâmetros) mais adequado à análise ${ }^{9}$. Essa adequação se estabelece em função de uma calibragem entre parâmetros que podem produzir resultados tautológicos e aqueles que produzem resultados nos quais seja impossível detectar algum tipo de correlação e recorrência. Escolhido o parâmetro, passa-se à segunda fase, que consiste na análise propriamente dita. Essa análise pode se valer de teorias já estabelecidas como também pode suscitar a proposição de novos procedimentos analíticos. A análise produz como resultado o que denominamos perfil composicional, o qual consiste em um conjunto de objetos específicos e relações entre esses

\footnotetext{
${ }^{8}$ É importante enfatizar que a modelagem sistêmica não se relaciona com a modelagem perceptual proposta por Edson Zampronha (1998). Enquanto na modelagem perceptual "a linguagem não mais está na obra. Ela está na escuta, no modelar da percepção no contínuo de possibilidades que é a composição" (p.261), a modelagem sistêmica ainda trabalha com a ideia de sistematicidade e sequencialidade, ou seja, se insere no âmbito de um paradigma tradicional. Vale ressaltar que, no entanto, é intenção nossa ampliar o escopo da pesquisa no sentido de incluir também o campo estésico.

${ }^{9}$ Neste trabalho, empregamos o conceito expandido de parâmetro (Pitombeira, 2018). Assim sendo, consideramos que há duas categorias de parâmetro: [1] Parâmetros superficiais, perceptíveis visual e auditivamente na superfície de uma textura musical (altura, duração, dinâmica etc.) e [2] Parâmetros abstratos, que se relacionam com os parâmetros de superfície por uma função não bijetora, de tal sorte que partindo de um parâmetro abstrato é impossível se chegar ao parâmetro superficial que the deu origem. São exemplos de parâmetros abstratos os contornos, os eixos inversivos, as partiçôes texturais, as formas primas etc.
} 
FERREIRA, Esdras Sarmento; SANTOS, Raphael Sousa; LIMA, Flávio Fernandes de; CARVALHO, Hugo Tremonte de; PITOMBEIRA, Liduino. Sistema Composicional Intermarkoviano. Revista Vórtex, Curitiba, v.8, n.2, p. 1-46, 2020.

objetos. $\mathrm{Na}$ última fase da modelagem sistêmica, denominada generalização paramétrica, os objetos são generalizados e tem-se como resultado um modelo sistêmico formado por objetos genéricos e suas interrelações. Tal modelo sistêmico é um sistema composicional hipotético.

Como exemplo de modelagem sistêmica, tomemos o trecho mostrado na Figura 2, terceiro movimento de Drei kleine Stücke, Op. 11, de Anton Webern $(1952)^{10}$. Na primeira fase da modelagem sistêmica dessa obra, selecionamos o parâmetro altura (mais precisamente, classe de altura) por apresentar uma maior variedade léxica e também por revelar, em uma análise prospectiva inicial, um resultado de caráter musicológico interessante, que pode indicar o uso da série cromática bem antes que Webern adotasse o dodecafonismo como técnica composicional ${ }^{11}$. A análise busca identificar objetos (classes de alturas) e suas interrelações para chegar a um perfil composicional da obra.

FIGURA 2 - Terceiro movimento de Drei kleine Stücke, Op. 11, de Anton Webern (1952).

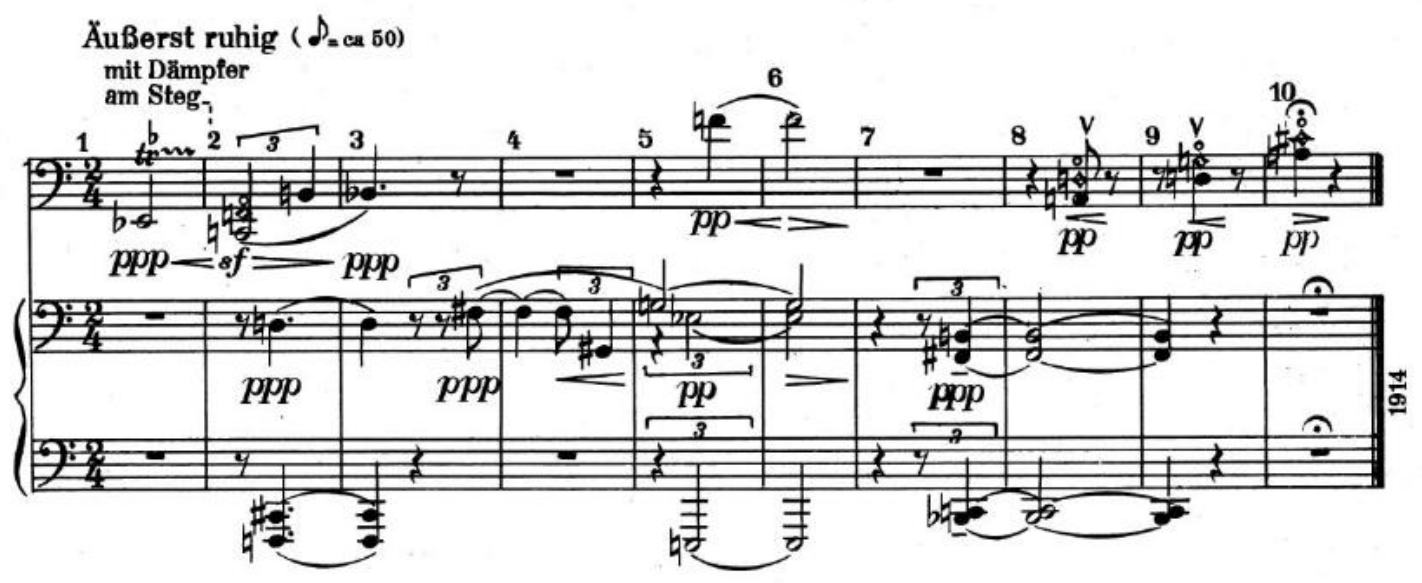

No grafo da Figura 3 podemos observar duas apresentações de uma série cromática: no formato “original” (praticamente linear), apresentada prioritariamente no violoncelo (430BA6875921), e no

\footnotetext{
${ }^{10}$ Obra composta em 1914, segundo indicação no final da partitura.

${ }^{11}$ A produção composicional de Anton Webern (1883-1945) pode ser dividida em cinco fases, segundo Kathryn Puffett (2001): obras juvenis, que demonstram uma tonalidade expandida (1899-1908), atonalidade aforística instrumental (1908-1914), novo lirismo atonal (1915-1926), dodecafonismo instrumental (1927-1940) e dodecafonismo vocal (19331943). Webern apresenta uma série linearmente pela primeira vez na terceira canção do Drei Volkstexte, Op.17, obra composta em 1924. O Op.11 (1914), aqui modelado, é a última obra da fase atonal aforística instrumental. É interessante perceber, já nessa obra, as raízes de uma busca pelo uso das doze notas cromáticas sem repetição, algo que aliás pode ser detectado mesmo em Richard Strauss (seção Von der Wissenschaft de Also sprach Zarathustra, de 1895) e em Charles Yves (Three-page Sonata, de 1905).
} 
FERREIRA, Esdras Sarmento; SANTOS, Raphael Sousa; LIMA, Flávio Fernandes de; CARVALHO, Hugo Tremonte de; PITOMBEIRA, Liduino. Sistema Composicional Intermarkoviano. Revista Vórtex, Curitiba, v.8, n.2, p. 1-46, 2020.

formato inverso (parcialmente linear), apresentada exclusivamente no piano (12567B9A0834) ${ }^{12}$. As classes de alturas são mostradas dentro de círculos. As setas (verdes e pretas) indicam o fluxo cromático, ou seja, indicam operações de sequenciamento de classes de alturas. Outra camada analítica pode ser evidenciada se agruparmos algumas classes de alturas para formar conjuntos tricordais. Separamos conjuntos contidos em retângulos rosas, correspondentes à classe [014], e outros em retângulos azuis, correspondentes à classe [012]. Esses conjuntos se relacionam entre si através das seguintes operações: verticalização, representada por uma seta vermelha, que verticaliza estruturas horizontais, e repetição variada, representada por uma seta azul, que apresenta uma forma transposta ou invertida do mesmo conjunto. Tanto a verticalização como a repetição variada alteram as formas normais dos conjuntos por meio de transposição $(T x)$ e inversão $(T x I)$, operações essas indicadas ao lado das setas. Se eliminarmos os objetos específicos de superfície e nos concentrarmos somente nas relaçốes entre objetos genéricos, chegaremos ao modelo sistêmico da obra, sob a perspectiva do método analítico adotado. Esse modelo sistêmico é mostrado no diagrama da Figura 4.

FIGURA 3 - Perfil composicional do terceiro movimento de Drei kleine Stücke, Op. 11, de Anton Webern (1952), segundo uma perspectiva de grafos.

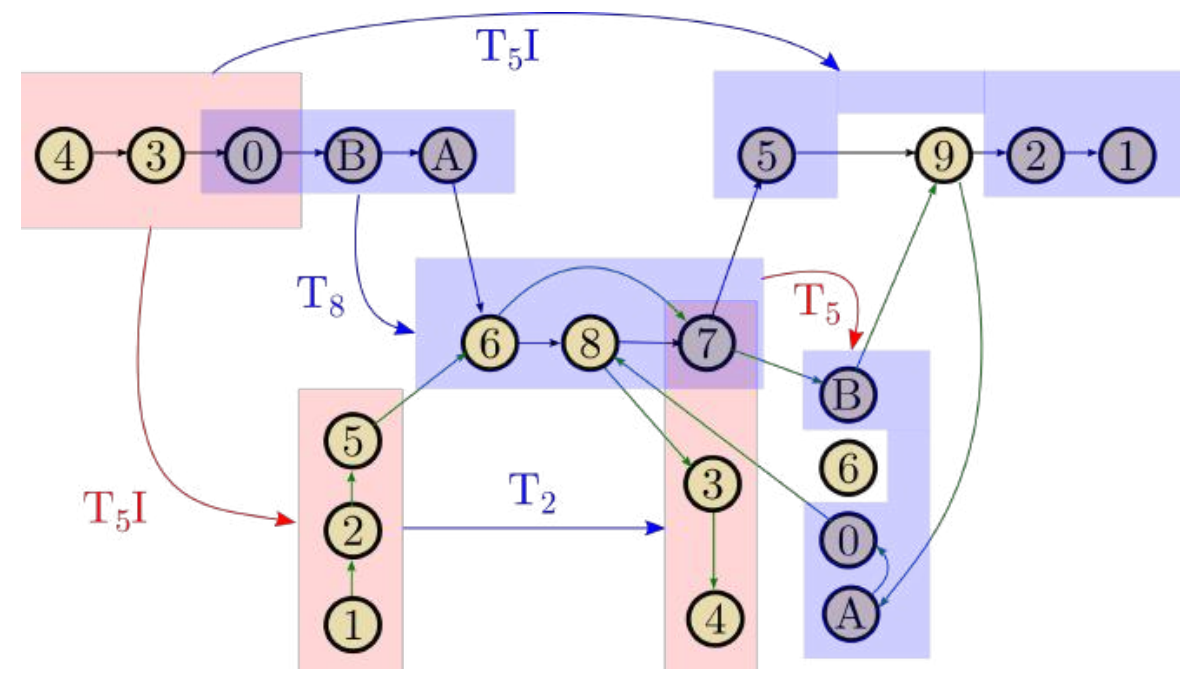

Partindo do modelo sistêmico mostrado na Figura 4, uma série de experimentos nos revelou que é praticamente impossível encontrar (pelo menos sem um auxílio computacional altamente

\footnotetext{
${ }^{12}$ Somente o primeiro hexacorde dessa série apresenta alguma direcionalidade clara.
} 
FERREIRA, Esdras Sarmento; SANTOS, Raphael Sousa; LIMA, Flávio Fernandes de; CARVALHO, Hugo Tremonte de; PITOMBEIRA, Liduino. Sistema Composicional Intermarkoviano. Revista Vórtex, Curitiba, v.8, n.2, p. 1-46, 2020.

especializado, como, por exemplo, de redes neurais de aprendizagem profunda) outra série, distinta da série utilizada por Webern, que satisfaça a todas as condições de conexão. Contudo, uma flexibilização em alguns aspectos do modelo sistêmico tornou o sistema viável. A primeira flexibilização se deu nas operações de transposição e inversão: tanto os fatores como as próprias operações em si foram flexibilizados para satisfazer os mapeamentos tricordais. Assim, as cinco operações foram generalizadas para $\mathrm{Ox}, \mathrm{Oy}, \mathrm{Oz}, \mathrm{Ow}$ e Ok. O tipo e o fator da operação serão decididos durante o planejamento composicional. O segundo aspecto a ser flexibilizado consistiu em eliminar a obrigatoriedade da segunda série se relacionar, por transposição, inversão, ou retrogradação, à série original. Com essas flexibilizaçóes foi possível propor um sistema composicional o mais próximo possível do modelo sistêmico oriundo do terceiro movimento do Op.11 de Webern. O diagrama desse novo sistema, denominado AW, é mostrado na Figura 5 e sua descrição formal é declarada na Tabela 1.

FIGURA 4 - Modelo sistêmico do terceiro movimento de Drei kleine Stücke, Op. 11, de Anton Webern (1952), segundo uma perspectiva de grafos.

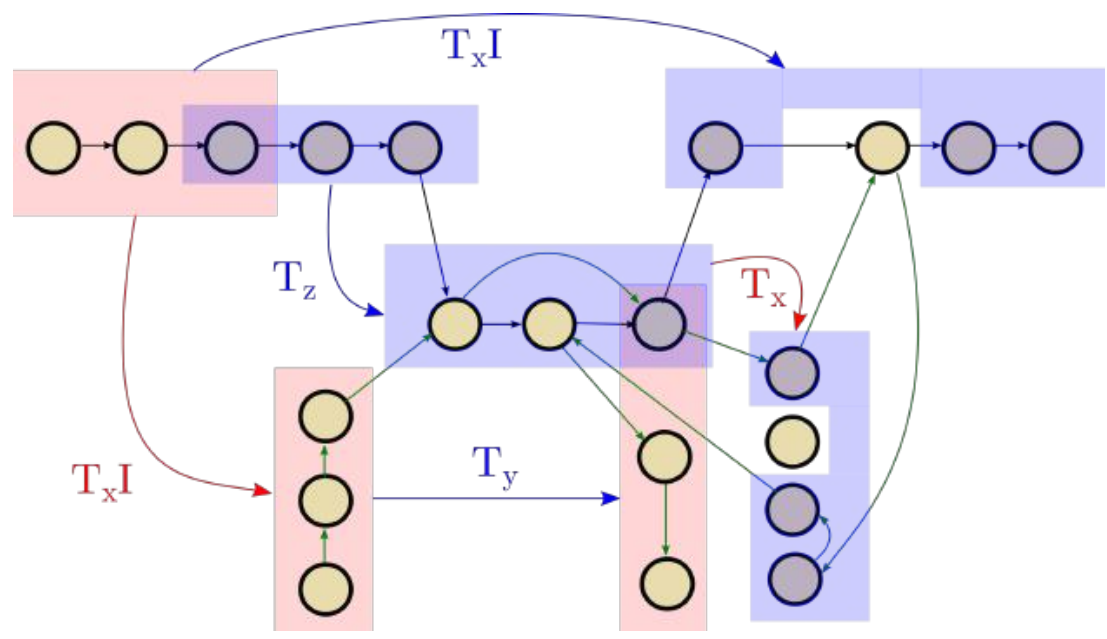


FERREIRA, Esdras Sarmento; SANTOS, Raphael Sousa; LIMA, Flávio Fernandes de; CARVALHO, Hugo Tremonte de; PITOMBEIRA, Liduino. Sistema Composicional Intermarkoviano. Revista Vórtex, Curitiba, v.8, n.2, p. 1-46, 2020.

FIGURA 5 - Modelo sistêmico viável do terceiro movimento de Drei kleine Stücke, Op. 11, de Anton Webern (1952), segundo uma perspectiva de grafos.

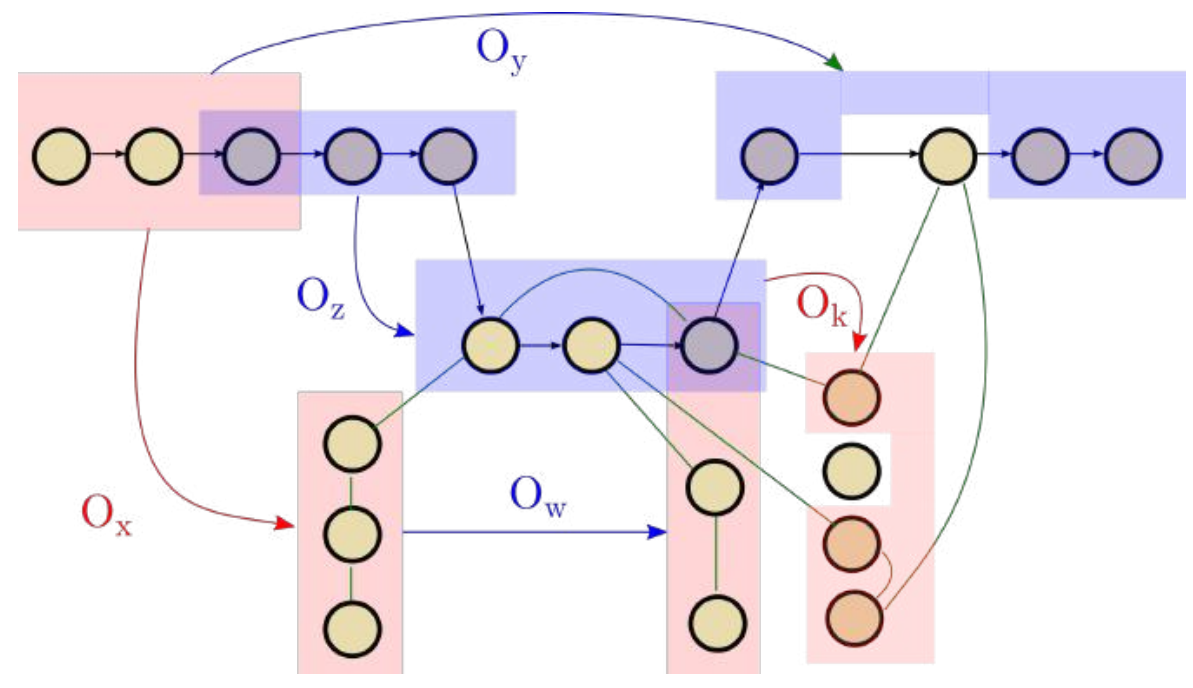

TABELA 1 - Sistema AW, oriundo da modelagem sistêmica do terceiro movimento de Drei kleine Stücke, Op. 11, de Anton Webern (1952), segundo uma perspectiva de grafos.

\begin{tabular}{|c|c|}
\hline DEFINIÇÃO 1 & $\begin{array}{l}\text { A obra se constrói pelo entrelaçamento de duas séries cromáticas. A primeira série tem uma } \\
\text { apresentação horizontal. A segunda série é predominantemente vertical. As séries não } \\
\text { precisam se relacionar entre si por transposição, inversão ou retrogradação. O grafo da Figura } \\
5 \text { mostra a primeira série, cujas classes de alturas são conectadas por setas pretas direcionais, e } \\
\text { a segunda série, cujas classes de alturas são conectadas por setas verdes não direcionais. }\end{array}$ \\
\hline DEFINIÇÃO 2 & $\begin{array}{l}\text { As séries são segmentadas em tricordes pertencentes a somente duas classes distintas, } \\
\text { definidas durante o planejamento composicional e identificadas no grafo da Figura } 5 .\end{array}$ \\
\hline DEFINIÇÃO 3 & $\begin{array}{l}\text { Uma série de operações de transposição e inversão conecta esses tricordes, de acordo com o } \\
\text { grafo mostrado na Figura } 5 \text {. }\end{array}$ \\
\hline DEFINIÇÃO 4 & Ritmo, timbre, dinâmica e articulação serão escolhidos livremente pelo compositor. \\
\hline
\end{tabular}

Partindo desse sistema composicional (Figura 5 e Tabela 1), realizamos o planejamento composicional de uma nova obra. Essa metodologia é efetivada em três fases. Na primeira fase, denominada particularização, conferimos valores particulares aos valores genéricos do sistema. As séries foram selecionadas por experimentos de tentativa e erro. A primeira série selecionada foi 0126734895AB e a segunda série 01238B56749A. Essas séries viabilizam a segmentação em duas classes tricordais: [012], inseridos em retângulos rosas, e [015], inseridos em retângulos azuis. 


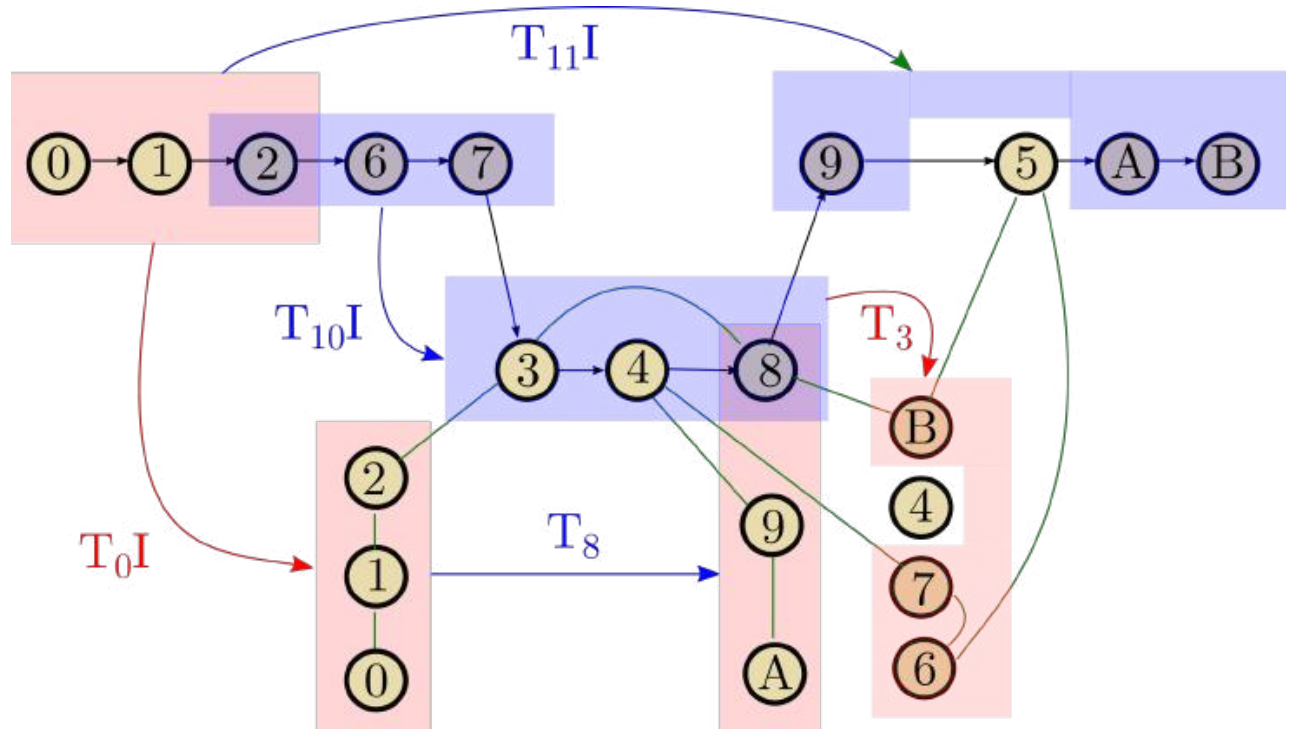

$\mathrm{Na}$ segunda fase do planejamento composicional, denominada aplicação, as classes de alturas são aplicadas à superfície musical ao lhes serem conferidos registros específicos. A aplicação gera um esboço inicial da obra em duas pautas (Figura 6). A terceira fase do planejamento composicional, denominada complementação, consiste na aplicação dos demais parâmetros não declarados no sistema. Orquestramos o esboço para quinteto de sopros, com andamento igual a 90 semínimas por minuto. Os ritmos, as articulaçôes e as dinâmicas foram livremente escolhidos. O resultado é a partitura mostrada na Figura 7 (sons reais).

FIGURA 6 - Esboço de alturas produzido pela aplicação das classes de alturas do sistema AW.

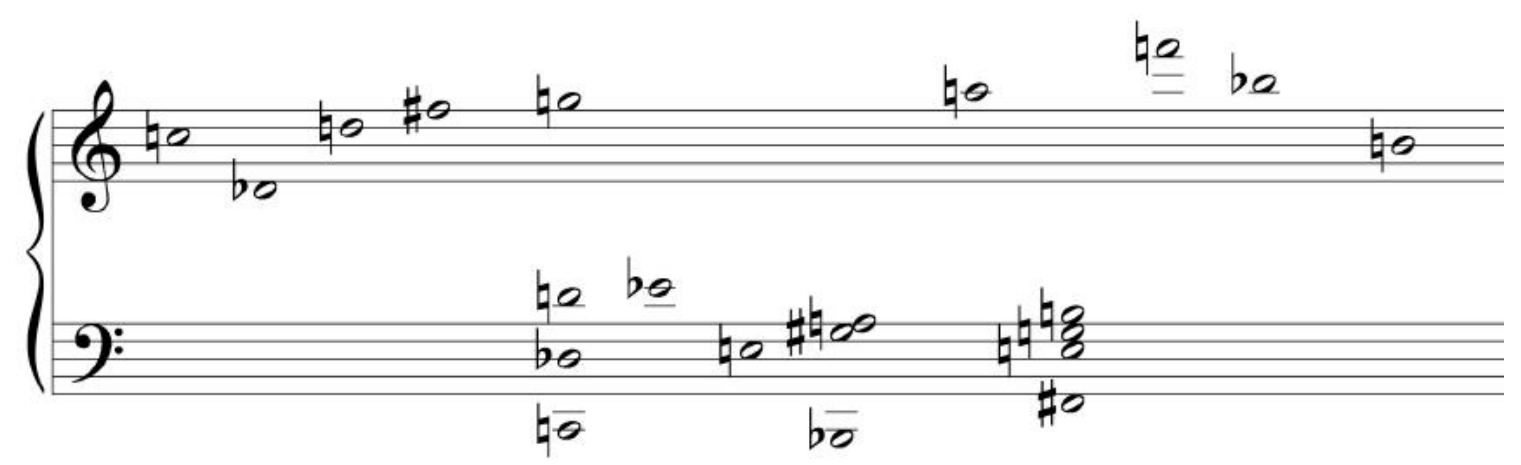


FERREIRA, Esdras Sarmento; SANTOS, Raphael Sousa; LIMA, Flávio Fernandes de; CARVALHO, Hugo Tremonte de; PITOMBEIRA, Liduino. Sistema Composicional Intermarkoviano. Revista Vórtex, Curitiba, v.8, n.2, p. 1-46, 2020.

FIGURA 7- Partitura gerada pela complementação do esboço gerado em um possível planejamento composicional partindo do sistema AW.

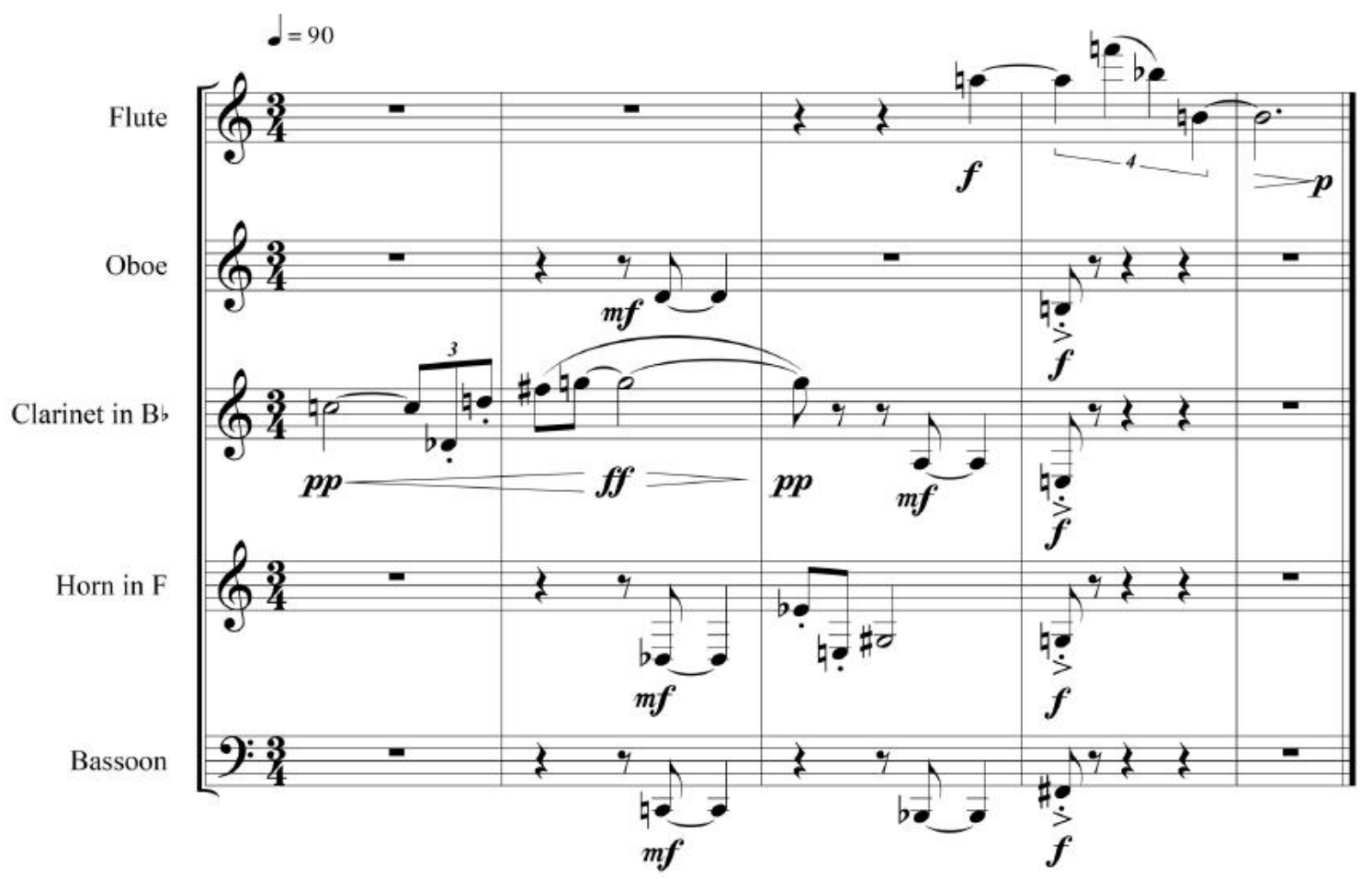

Uma análise comparativa entre a nova obra produzida por modelagem sistêmica e a obra original de Webern pode nos revelar similaridades e diferenças. Uma similaridade clara é percebida no aspecto textural, especialmente no que concerne à tendência pontilhista de ambas as obras, ou seja, ambas apresentam uma textura rarefeita. A sonoridade atonal, presente nas duas obras, é herdada da obra original e impressa nas próprias definiçôes sistêmicas, de tal forma que qualquer planejamento partindo do mesmo sistema apresentará esse tipo de sonoridade. As diferenças mais salientes se concentram no timbre e na dinâmica.

Um sistema composicional, tanto modelado como original, pode ser classificado, quanto à sua arquitetura, como aberto, semiaberto ou retroalimentado. O sistema aberto apresenta em sua configuração entrada e a saída de materiais ou parâmetros. Esse tipo de sistema pode ser visto flexivelmente como uma função ou conjunto de funções que realizam transformaçóes em parâmetros e/ou materiais musicais. Um exemplo desse tipo de sistema composicional é mostrado na Figura 8, na qual um fragmento musical, mostrado na parte superior da figura, é inserido no sistema. 
FERREIRA, Esdras Sarmento; SANTOS, Raphael Sousa; LIMA, Flávio Fernandes de; CARVALHO, Hugo Tremonte de; PITOMBEIRA, Liduino. Sistema Composicional Intermarkoviano. Revista Vórtex, Curitiba, v.8, n.2, p. 1-46, 2020.

FIGURA 8 - Sistema composicional aberto: o fragmento musical na parte superior é inserido no sistema. Uma faixa de alturas é selecionada e submetida à filtragem ou inversão. O resultado é concatenado gerando novo fragmento (parte inferior).

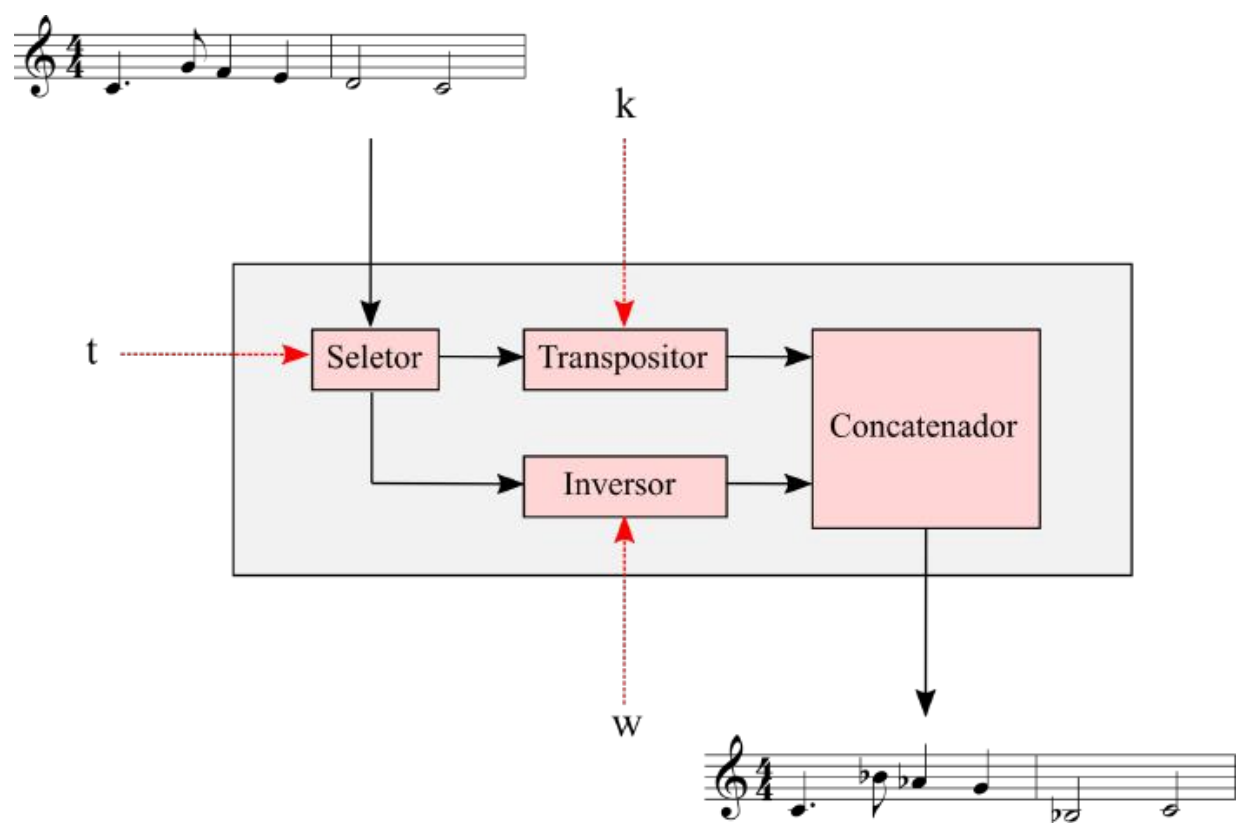

Esse sistema lida especificamente com o parâmetro altura, sendo os demais parâmetros desconsiderados. Uma variável de controle $t$ define um ponto de corte para o seletor, módulo que separa o trecho em duas partes. No caso específico desse exemplo, $t=62$ (valor MIDI que equivale a $\mathrm{Ré}_{4}$, se considerarmos que o Dó central do piano vale 60). Assim, alturas acima de Ré 4 serão enviadas a um módulo transpositor enquanto as demais alturas serão enviadas a um módulo inversor. Por sua vez, tanto o transpositor como o inversor têm variáveis de controle. A variável $k$ indica o número de semitons de transposição; a variável $w$ indica o eixo em torno do qual será realizada a inversão. No nosso exemplo $k=3$ e $w=60$, indicando que o trecho selecionado será transposto em 3 semitons e a inversão ocorrerá em torno de 60 (Dó $)_{4}$. As saídas do transpositor e do inversor são enviadas a um módulo concatenador produzindo o trecho final. Assim, em nosso sistema aberto as alturas Dó e Ré serão invertidas em torno de Dó e as alturas Sol, Fá e Mi serão transpostas uma terça menor acima.

O sistema semiaberto apresenta apenas saída de materiais, ou seja, não há entrada de materiais ou parâmetros (exceto variáveis de controle). Exemplos desse tipo de sistema são o sistema 
FERREIRA, Esdras Sarmento; SANTOS, Raphael Sousa; LIMA, Flávio Fernandes de; CARVALHO, Hugo Tremonte de; PITOMBEIRA, Liduino. Sistema Composicional Intermarkoviano. Revista Vórtex, Curitiba, v.8, n.2, p. 1-46, 2020.

parcimonioso mostrado na Figura $1^{13}$, bem como os geradores randômicos de parâmetros. Na Tabela 2, mostramos o projeto de um sistema composicional semiaberto que tem por núcleo um gerador randômico. Esse sistema, denominado SR, é constituído por seis definições.

TABELA 2 - Sistema composicional semiaberto randômico (SR).

\begin{tabular}{|c|c|}
\hline DEFINIÇÃO 1 & $\begin{array}{l}\text { Propóe-se a construção randômica de duas linhas de classes de alturas, as quais podem ser } \\
\text { distribuídas em diversas outras linhas durante a fase de planejamento. }\end{array}$ \\
\hline DEFINIÇÃO 2 & $\begin{array}{l}\text { As alturas serão oriundas de dois hexacordes A e B. Cada hexacorde fornecerá material para } \\
\text { uma linha específica. As classes de alturas componentes de cada hexacorde serão } \\
\text { armazenadas em tabelas indexadas }(1,2,3,4,5,6) \text {. }\end{array}$ \\
\hline DEFINIÇÃO 3 & $\begin{array}{l}\text { Uma escala rítmica de seis valores será construída na fase de planejamento. Esses valores serão } \\
\text { armazenados em uma tabela indexada. }\end{array}$ \\
\hline DEFINIÇÃO 4 & $\begin{array}{l}\text { Pausas são distribuídas livremente e classes de alturas repetidas podem ser agrupadas } \\
\text { produzindo uma figura rítmica de maior valor. }\end{array}$ \\
\hline DEFINIÇÃO 5 & $\begin{array}{l}\text { Através do sorteio de um dado de seis faces, são escolhidos simultaneamente os valores de } \\
\text { alturas e figuras rítmicas, os quais são dispostos ordenadamente em cada linha. }\end{array}$ \\
\hline DEFINIÇÃO 6 & Timbre, dinâmica e articulação serão escolhidos livremente pelo compositor. \\
\hline
\end{tabular}

A Definição 1 explicita a função e o modo operacional do sistema. Com base nessa definição fica claro que o sistema lida com a produção de duas linhas de classes de alturas (isto é, sem registro especificado) a partir de procedimentos randômicos. As Definiçóes 2-4 tratam das variáveis de controle que serão particularizadas pelo compositor na fase de planejamento composicional. A Definição 5 explica como são gerados os valores, ou seja, pelo lançamento de um dado de seis faces. Por último, a Definição 6 menciona o tratamento a ser dado aos parâmetros não declarados.

$\mathrm{Na}$ Tabela 3, apresentamos um possível planejamento composicional para o sistema SR. O planejamento consiste basicamente na escolha dos dois hexacordes ( $\mathrm{A}$ e $\mathrm{B}$ ) e das seis figuras rítmicas. Posto em funcionamento (por um algoritmo computacional ou pelo lançamento de um dado real de seis faces) o sistema produziu o esqueleto de valores mostrados na Figura 9, ao qual foram adicionados pausas, timbres, andamento, dinâmicas e articulaçóes (Figura 10).

\footnotetext{
${ }^{13}$ No sistema parcimonioso da Figura 1 não se deve confundir a atribuição de valores particulares aos valores genéricos inerentes ao sistema com a entrada de materiais, procedimento que é claro ao se examinar o modus operandi do sistema aberto (Figura 2).
} 
FERREIRA, Esdras Sarmento; SANTOS, Raphael Sousa; LIMA, Flávio Fernandes de; CARVALHO, Hugo Tremonte de; PITOMBEIRA, Liduino. Sistema Composicional Intermarkoviano. Revista Vórtex, Curitiba, v.8, n.2, p. 1-46, 2020.

TABELA 3 - Planejamento composicional com base no sistema composicional semiaberto randômico (SR).

\begin{tabular}{cccc}
\hline Índice & Hexacorde A & Hexacorde B & Figuras rítmicas \\
\hline $\mathbf{1}$ & 0 & 1 & Mínima \\
$\mathbf{2}$ & 2 & 3 & Semínima \\
$\mathbf{3}$ & 4 & 5 & Semínima pontuada \\
$\mathbf{4}$ & 6 & 7 & Colcheia \\
$\mathbf{5}$ & 8 & 9 & Colcheia pontuada \\
$\mathbf{6}$ & 10 & 11 & Semicolcheia \\
\hline
\end{tabular}

FIGURA 9 - Resultado do sorteio de dados do sistema SR, produzindo duas linhas de classes de alturas.

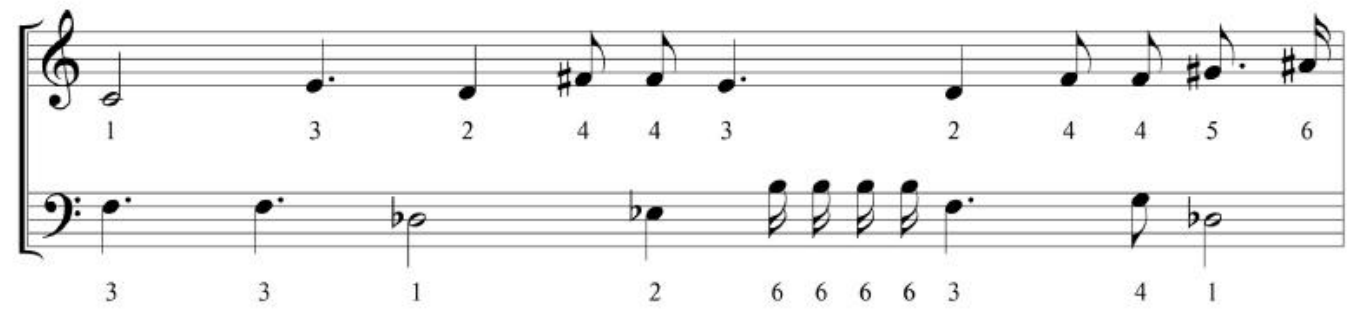

FIGURA 10 - Inclusão de pausas e de outros parâmetros nos resultados produzidos pelo sistema SR.

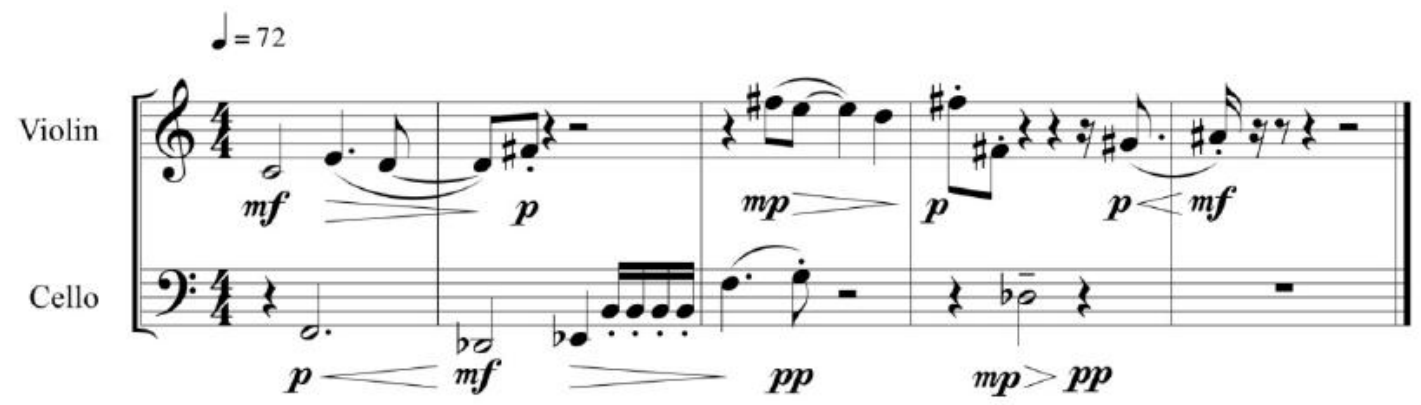

Um sistema retroalimentado pode ser construído com base em processos iterativos e é geralmente associado a sistemas dinâmicos não-lineares (caos determinístico) ${ }^{14}$. Utilizamos como exemplo o oscilador de Van der Pol, um sistema caótico de uma dimensão, que evolui no tempo segundo a Equação 1.

\footnotetext{
${ }^{14}$ Um exemplo de sistema retroalimentado sem o uso de sistemas dinâmicos não-lineares pode ser examinado em Pitombeira (2020, p.56-57).
} 
FERREIRA, Esdras Sarmento; SANTOS, Raphael Sousa; LIMA, Flávio Fernandes de; CARVALHO, Hugo Tremonte de; PITOMBEIRA, Liduino. Sistema Composicional Intermarkoviano. Revista Vórtex, Curitiba, v.8, n.2, p. 1-46, 2020.

$$
\frac{d^{2} x}{d t^{2}}-\mu\left(1-x^{2}\right) \frac{d x}{d t}+x=0
$$

Um programa em Python, elaborado por John Cook (2019) nos permitiu produzir resultados para três valores de $\mu^{15}$. Nos interessam particularmente os valores 1 e 2 , que produzem um estado caótico no sistema. Selecionamos $\mu=2$, normalizamos os resultados para a faixa de valores MIDI (0127) e, através da biblioteca music21, produzimos um arquivo MIDI (Figura 11). Partindo unicamente desse conjunto de alturas, produzimos um trecho para trompete, trompa e tuba (mostrado no Apêndice 3), através da aplicação de diversas operações, tais como transposição, expansão temporal e inversão ${ }^{16}$.

FIGURA 11 - Alturas produzidas pelo oscilador Van der Pol.

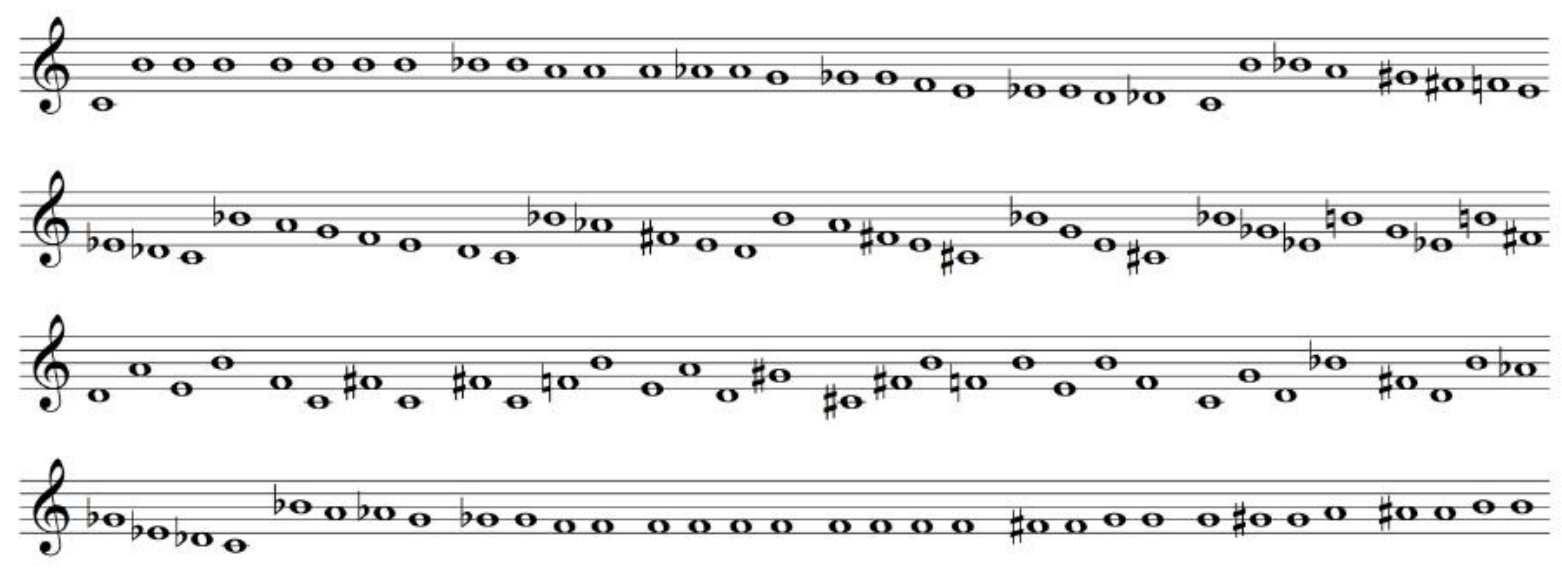

Fizemos, nesta Seção, uma rápida descrição e exemplificação de conceitos fundamentais à teoria dos sistemas composicionais. Essa teoria, vem sendo construída desde 2010 e ao longo desses dez anos vem passando por diversos ajustes e expansões, decorrentes principalmente dos experimentos

\footnotetext{
${ }^{15}$ Este programa está disponibilizado no Apêndice 2.

${ }^{16}$ Inicialmente atribuímos ritmo a esse conjunto de alturas e distribuímos entre os instrumentos. Para os doze primeiros compassos, a linha melódica está localizada no trompete. Os materiais dos compassos 4, 8 e 12 são expandidos temporalmente em 4 vezes (ou seja, colcheias transformam em mínimas), transpostos respectivamente em dois, cinco e cinco semitons abaixo e dispostos na trompa. O material da tuba é uma transposição 15 semitons abaixo do material da trompa. A partir desse ponto outras transformações similares foram aplicadas mantemos uma organicidade e consistência interna da obra.
} 
FERREIRA, Esdras Sarmento; SANTOS, Raphael Sousa; LIMA, Flávio Fernandes de; CARVALHO, Hugo Tremonte de; PITOMBEIRA, Liduino. Sistema Composicional Intermarkoviano. Revista Vórtex, Curitiba, v.8, n.2, p. 1-46, 2020.

realizados ${ }^{17}$. A definição do conceito de sistema composicional deriva, de certa forma, dos trabalhos de George Klir (1991) e Ludwig von Bertalanffy (2008). Para esse último “um sistema é um conjunto de elementos em interação” (BERTALANFFY, 2008, p. 84). Esse autor hierarquiza os sistemas, colocando a música e as artes em geral, juntamente com a linguagem, em um nível hierárquico denominado sistemas simbólicos. Por sua vez, Klir (1991, p. 4) formaliza uma definição de senso comum, extraída do Webster's New World Dictionary, em tradução livre dos autores: "um conjunto ou arranjo de coisas relacionadas ou conectadas de tal maneira para formar uma unidade ou todo orgânico" ${ }^{18}$.

Em uma definição formal, podemos denotar o sistema, representado pela letra $S$, como um par $(O, R)$, onde $O$ representa o conjunto de objetos e $R$ o conjunto de relaçóes entre esses objetos. A partir dessa definição se observa que um sistema necessita simultaneamente de objetos e relações. Assim, um conjunto de notas musicais em uma partitura, por exemplo, não é um sistema, mas simplesmente um aglomerado de objetos simbólicos. Contudo, quando organizamos essas notas de alguma forma, por exemplo, através de uma regra de ordenação, essa coleção de notas passa a constituir um sistema. Como é afirmado por Klir (1991, p. 5), essa definição é aparentemente simples na superfície, embora seja extremamente geral e aberta, e tem a capacidade de conter todas as demais definiçóes de sistema ${ }^{19}$. Partindo destes princípios, desenvolvemos o Sistema Composicional Intermarkoviano, que encapsula em um aplicativo computacional um conjunto de algoritmos que gerenciam materiais intertextuais por meio de uma sintaxe oriunda das cadeias de Markov. Como a intertextualidade é um fundamento teórico essencial para a elaboração desse sistema, passaremos a examiná-la na Seção 2.

\footnotetext{
${ }^{17}$ Muitos desses experimentos estão documentados em artigos e disponíveis gratuitamente em https://ufrj.academia.edu/LiduinoPitombeira.

${ }^{18} \mathrm{O}$ Webster online (http://www.merriam-webster.com) apresenta diversas definições, de certa maneira, similares à citada por Klir (1991).

${ }^{19}$ Uma leitura do início do Capítulo 2 de KLIR (1991) nos revela que essa definição pode englobar sistemas bastante complexos, dependendo dos objetos e das relações.
} 
FERREIRA, Esdras Sarmento; SANTOS, Raphael Sousa; LIMA, Flávio Fernandes de; CARVALHO, Hugo Tremonte de; PITOMBEIRA, Liduino. Sistema Composicional Intermarkoviano. Revista Vórtex, Curitiba, v.8, n.2, p. 1-46, 2020.

\section{Intertextualidade}

A teoria da intertextualidade trata da reciclagem de ideias já existentes, como forma de desenvolvimento de novos materiais. Para Bakhtin (1981, p. 304), esse processo denomina-se construção híbrida. Kristeva (2006, p. 68), por sua vez, parte do princípio de que "todo texto se constrói como um mosaico de citações, todo texto é absorção e transformação de outro texto. Assim sendo, um texto é, de certa maneira, ele próprio e outro - ou outros - que o precede $(\mathrm{m}) ”$.

Atualmente, o termo “intertextualidade" tem seu enfoque intrínseco voltado também à linguagem musical, tanto do ponto de vista teórico, notadamente nos trabalhos de Straus (1990), Korsyn (1991) e Klein (2005), bem como do ponto de vista composicional propriamente dito, como se observam em obras de Rochberg e Berio, por exemplo.

Straus (1990, p. 17) relaciona oito procedimentos composicionais, comuns aos compositores da primeira metade do século XX, utilizados na reconstrução de formas antigas, elementos de estilo e sonoridades. Tais procedimentos são verdadeiras ferramentas que podem ser utilizadas para manipular intertextos, gerando como resultado obras originais. Os procedimentos relacionados por Straus são:

[1] Motivização: O conteúdo motívico do trabalho precedente é radicalmente intensificado; [2] Generalização: Um motivo do trabalho precedente é generalizado no conjunto de classes de alturas desordenado, do qual é um membro. Este conjunto de classes de alturas é então desdobrado no novo trabalho, de acordo com as normas do uso pós-tonal; [3] Marginalização: Os elementos musicais que são centrais à estrutura do trabalho precedente (tais como cadências dominante-tônica e progressôes lineares que abrangem intervalos triádicos) são relegados à periferia do novo trabalho; [4] Centralização: Os elementos musicais que são periféricos à estrutura do trabalho precedente (tais como áreas de tonalidade remota e combinaçốes não usuais das notas resultantes de ornamentaçôes lineares) movem-se para o centro estrutural do novo trabalho; [5] Compressão: Os elementos que ocorrem diacronicamente no trabalho precedente (tais como duas tríades numa relação funcional a cada outra) são comprimidos em algo síncrono no novo trabalho; [6] Fragmentação: Os elementos que ocorrem juntos no trabalho precedente (tais como a fundamental, a terça, e a quinta de uma tríade) são separados no novo trabalho; [7] Neutralização: Os elementos musicais tradicionais (tais como acordes de sétima da dominante) são desnudados de suas funçôes de costume, particularmente de seu impulso progressivo. A progressão para adiante é bloqueada; e [8] Simetrização: Progressões harmônicas e formas musicais tradicionalmente orientadas para um objetivo (forma sonata, por exemplo) são feitas inversamente ou retrógrada-simetricamente, e são assim 
FERREIRA, Esdras Sarmento; SANTOS, Raphael Sousa; LIMA, Flávio Fernandes de; CARVALHO, Hugo Tremonte de; PITOMBEIRA, Liduino. Sistema Composicional Intermarkoviano. Revista Vórtex, Curitiba, v.8, n.2, p. 1-46, 2020.

imobilizadas ${ }^{20}$.

Reforçando a enorme importância da intertextualidade como procedimento composicional, Kaplan (2006, p. 19) afirma que "fora da intertextualidade uma obra musical é simplesmente incompreensível”. Desta maneira, podemos manipular materiais já desenvolvidos por outros compositores, criando diferentes visóes do mesmo ponto de partida e abrindo um grande leque de possibilidades à inovação no trabalho composicional.

Neste trabalho, utilizamos o conceito de intertextualidade abstrata, em oposição à intertextualidade literal. Lima (2011, p.48) fala de

duas perspectivas de utilização da intertextualidade - literal ou abstrata, patente ou latente, manifesta ou velada, assumida ou dissimulada - [que] nos permite tratar os intertextos em diversos níveis, desde o mais literalmente superficial até o mais profundo, onde apenas elementos estruturais ou oriundos de operações transformacionais são utilizados, através do uso de ferramentas intertextuais específicas

Uma ferramenta útil, tanto para a compreensão das noções de intertextualidade literal e abstrata bem como para uma aplicação racional das diversas modalidades de intertextualidade na música, é a bússola intertextual, desenvolvida por Gabriel Mesquita (2018), mostrada na Figura 12.

A bússola categoriza nove modalidades de intertextualidade, segundo os critérios de presença e intencionalidade, revelando uma gradação da mais literal (citação) à mais abstrata (modelagem sistêmica). A presença se relaciona com o material temático do intertexto, enquanto a intencionalidade diz respeito ao contexto no qual o material temático é inserido. Desta forma, em

\footnotetext{
${ }^{20}$ No original lê-se: "[1] Motivicization: The motivic content of the earlier work is radically intensified; [2] Generalization: A motive from the earlier work is generalized into the unordered pitch-class set of which it is a member. That pitch-class set is then deployed in the new work in accordance with the norms of post-tonal usage; [3] Marginalization: Musical elements that are central to the structure of the earlier work (such as dominant-tonic cadences and linear progressions that span triadic intervals) are relegated to the periphery of the new one; [4] Centralization: Musical elements that are peripheral to the structure of the earlier work (such as remote key areas and unusual combinations of notes resulting from linear embellishment) move to the structural center of the new one; [5] Compression: Elements that occur diachronically in the earlier work (such as two triads in a functional relationship to each other) are compressed into something synchronous in the new one; [6] Fragmentation: Elements that occur together in the earlier work (such as the root, third, and fifth of a triad) are separated in the new one; [7] Neutralization: Traditional musical elements (such as dominant-seventh chords) are stripped of their customary function, particularly of their progressional impulse. Forward progress is blocked; and [8] Symmetricization: Traditionally goal-oriented harmonic progressions and musical forms (sonata form, for example) are made inversionally or retrograde-symmetrical, and are thus immobilized". Tradução nossa.
} 
uma paródia o contexto é subvertido, mas a presença temática é explícita; por outro lado, em um pastiche, ocorre o inverso: o contexto é o mesmo do intertexto, mas o material temático é totalmente implícito. Essas duas modalidades ocupam na bússola posiçôes diametralmente opostas. Da mesma forma, na citação literal, tudo é identificável: material temático e contexto. Contrariamente, na modelagem sistêmica, tanto o material temático, como o contexto estão o mais distante possível do original. A perspectiva da bússola intertextual corrobora os resultados mostrados na seção anterior deste trabalho, quando realizamos a modelagem sistêmica de uma obra aforística de Webern (Op.11).

FIGURA 12 - A bússola intertextual de Gabriel Mesquita (2018)

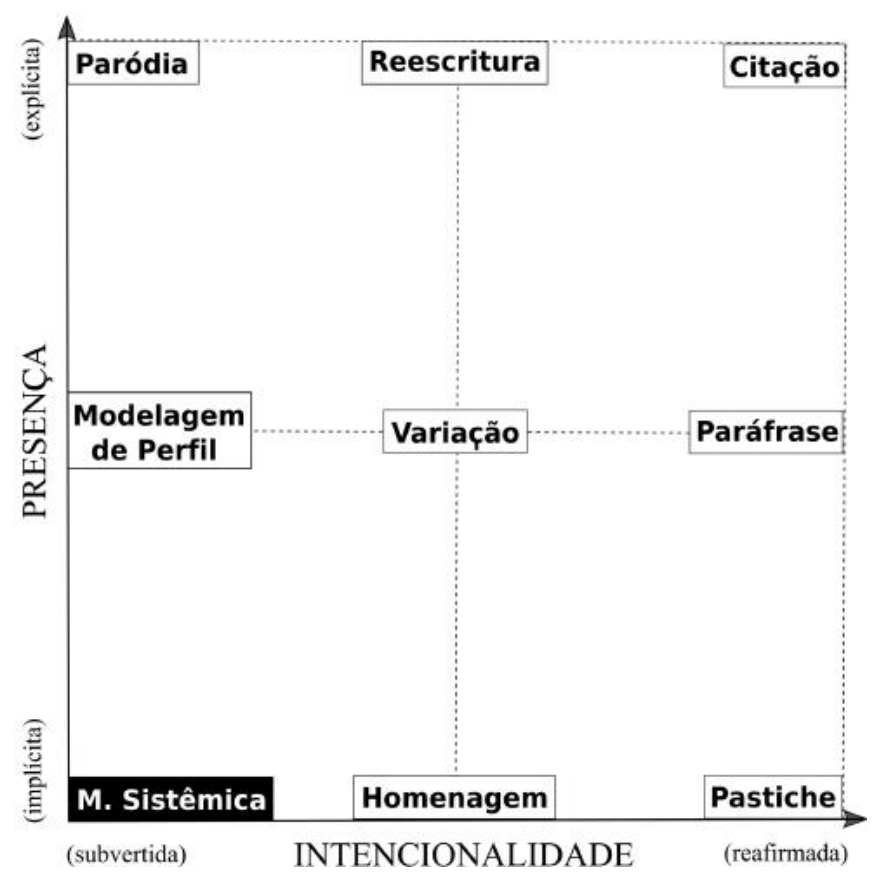

Tendo em mente que a modelagem sistêmica é um tipo de intertextualidade que lida com parâmetros prioritariamente abstratos ou com relações entre parâmetros superficiais, modelamos o segundo movimento dos Cinco Movimentos para Quarteto de Cordas Op. 5, de Anton Webern, para, por meio de suas configurações de contorno melódico e partições texturais rítmicas, ambos parâmetros abstratos, propor o Sistema Composicional Intermarkoviano, o qual será o ponto de partida para a criação do primeiro movimento de Plate Two: Érebo. Esse sistema, como veremos na Seção 6, se utiliza de cadeias de Markov para gerenciar computacionalmente o aspecto sintático das relaçôes entre os parâmetros abstratos (léxico) que foram a base da construção do modelo sistêmico. 
FERREIRA, Esdras Sarmento; SANTOS, Raphael Sousa; LIMA, Flávio Fernandes de; CARVALHO, Hugo Tremonte de; PITOMBEIRA, Liduino. Sistema Composicional Intermarkoviano. Revista Vórtex, Curitiba, v.8, n.2, p. 1-46, 2020.

Nas duas próximas seções faremos uma breve descrição da teoria dos contornos e da análise particional.

\section{Teoria dos contornos}

A ideia de contorno surge intuitivamente com o ato de analisar a silhueta de melodias. Como exemplo disto, temos as análises dos contornos realizadas em melodias no início do século XX, feitas por George Herzog (1928). Entretanto, na condição de teoria, os contornos foram apresentados por Michael Friedmann em 1985. Segundo Marcos Sampaio (2012, p. 1):

Contorno é o perfil, desenho ou formato de um objeto. Contornos podem ter duas ou mais dimensões e podem relacionar altura a comprimento, largura ou tempo. Em música, contornos podem ser abstraídos de um parâmetro em relação a outro. Contornos melódicos, por exemplo, são abstraçóes do movimento de altura de notas em relação ao tempo. É possível abstrair contornos de qualquer parâmetro musical como altura, densidade, ritmo, timbre e intensidade.

Em nosso sistema composicional, utilizamos contornos referentes exclusivamente às alturas. Empregaremos na representação de contornos a notação amplamente utilizada na literatura, que consiste no estabelecimento de uma correspondência biunívoca entre números inteiros e alturas, de forma que o menor número representa a menor altura, o maior número representa a maior altura e os números intermediários representam as alturas intermediárias. Assim, por exemplo, o contorno do primeiro conjunto de alturas da Figura 13 pode ser representado por $<021>$. As relaçôes de contornos nos permitem ainda perceber semelhanças profundas entre conjuntos que aparentemente não apresentam similaridades. Vejamos, ainda na Figura 13, como todos os conjuntos, embora pertencentes a classes de conjuntos distintas, apresentam o mesmo contorno. 
FIGURA 13 - Três classes de conjuntos diferentes dispostas com as mesmas relações de contorno.

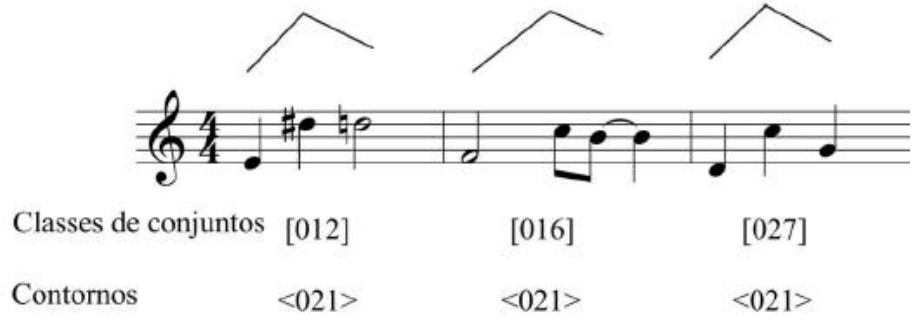

Os contornos melódicos serão segmentados no presente trabalho de acordo com os seguintes delimitadores: 1) Pausas; 2) Ligaduras de articulação indicadas pelo compositor; 3) Notas cuja duração seja maior que a nota anterior e a posterior. Este último critério foi definido por James Tenney e Larry Polansky (1980, p. 208-209) como um dos fatores de delimitação das unidades temporais gestálticas denominadas clangs. Robert Morris (1993, p.209) também define alguns critérios de segmentação em sua análise do Op.19, n.4, de Arnold Schoenberg: "ligaduras e outras formas de articulação, pontos de separação, contorno e afinidade referencial”21.

\section{Partições texturais rítmicas}

De acordo com Wallace Berry (1987, p. 184), “a textura da música consiste nos componentes sonoros que acontecem simultaneamente ou em concorrência, sendo esta qualidade determinada pelas interações, interrelações, projeções relativas e substâncias das linhas componentes ou outros fatores componentes sonoros”.

A aplicação da textura envolve a determinação de aspectos quantitativos, tais como densidadenúmero e densidade-compressão e de aspectos qualitativos, tais como as relaçôes de dependência e interdependência textural. A metodologia proposta por Berry foi posteriormente, expandida por Gentil-Nunes (2009) com a Análise Particional22. Para a determinação das relaçôes de dependência/independência entre partes de uma textura musical, utilizam-se partiçôes de números inteiros $\left(\begin{array}{lll}1 & \mathrm{a} & n\end{array}\right)$ que rotulam o grau de dependência entre $n$ camadas, sendo 1 o máximo de

\footnotetext{
${ }^{21}$ No original lê-se: "Slurs and other forms of articulation, punctuating gaps, shape, and referential affinity".

${ }^{22}$ A Análise Particional é uma convergência da Teoria das Partições de Euler (ANDREWS, 1984) com a Teoria Textural de Berry (BERRY, 1987).
} 
FERREIRA, Esdras Sarmento; SANTOS, Raphael Sousa; LIMA, Flávio Fernandes de; CARVALHO, Hugo Tremonte de; PITOMBEIRA, Liduino. Sistema Composicional Intermarkoviano. Revista Vórtex, Curitiba, v.8, n.2, p. 1-46, 2020.

independência e $n$ o máximo de dependência. Em Berry (1987), o grau de dependência pode ser definido a partir de critérios rítmicos, direcionais e intervalares. No Sistema Composicional Intermarkoviano, assim como no particionamento rítmico de Gentil-Nunes (2009), o critério que garante a interdependência entre as camadas texturais é exclusivamente o ritmo.

$\mathrm{Na}$ Figura 14, a título de exemplo, temos um trecho para quarteto de cordas elaborado por um dos autores do presente trabalho, no qual são determinadas as relações de dependência textural, de acordo com o critério rítmico, isto é, camadas com a mesma figuração rítmica são dependentes e camadas com figurações rítmicas diferentes são independentes. Nessa análise considerou-se o compasso como janela de observação ${ }^{23}$. Como estamos lidando com quatro camadas, o número 4 representa o máximo de dependência textural, ou seja, uma estrutura homorrítmica, algo que ocorre somente no último compasso do trecho. No penúltimo compasso, temos os dois violinos e a viola executando o mesmo ritmo, em contraste com o ritmo do violoncelo. O violoncelo é, portanto, singular (1) e os demais se aglomeram formando um bloco com três componentes (3). No antepenúltimo compasso temos dois blocos com dois componentes cada: um bloco formado pelos violinos (2) e outro pela viola e pelo violoncelo (2). No terceiro compasso todos os instrumentos se diferenciam no aspecto rítmico, ou seja, são três componentes independentes e singulares. Desta forma, cada um recebe a partição 1. O mesmo ocorre no segundo compasso só que apenas entre os dois violinos (1 1). O primeiro compasso é solo e, portanto, recebe a partição $1^{24}$.

\footnotetext{
${ }^{23}$ No aplicativo Parsemat, desenvolvido por Gentil-Nunes (2009), é possível determinar a dimensão da janela de observação. Se considerarmos que as partições texturais rítmicas devem ser indicadas em nível microscópico, a partir das alterações dos pontos de ataque e das duraçóes no interior de cada compasso, o terceiro compasso tem partiçóes 1.1, 1.1.1 e o quarto compasso 1.1.2 (uma vez que a nota ligada do violoncelo produz uma duração diferente da nota da viola)

${ }^{24} \mathrm{~A}$ análise particional define uma série de operaçôes de interrelacionamento entre as partiçôes (redimensionamento, transferência, revariância etc.). Como essas operaçôes não serão utilizadas no presente trabalho convidamos o leitor a consultar a bibliografia especializada, caso tenha interesse em um maior aprofundamento.
} 
FERREIRA, Esdras Sarmento; SANTOS, Raphael Sousa; LIMA, Flávio Fernandes de; CARVALHO, Hugo Tremonte de; PITOMBEIRA, Liduino. Sistema Composicional Intermarkoviano. Revista Vórtex, Curitiba, v.8, n.2, p. 1-46, 2020.

FIGURA 14 - Relações de dependência textural, considerando-se o compasso como janela de observação (Exemplo elaborado pelos autores).

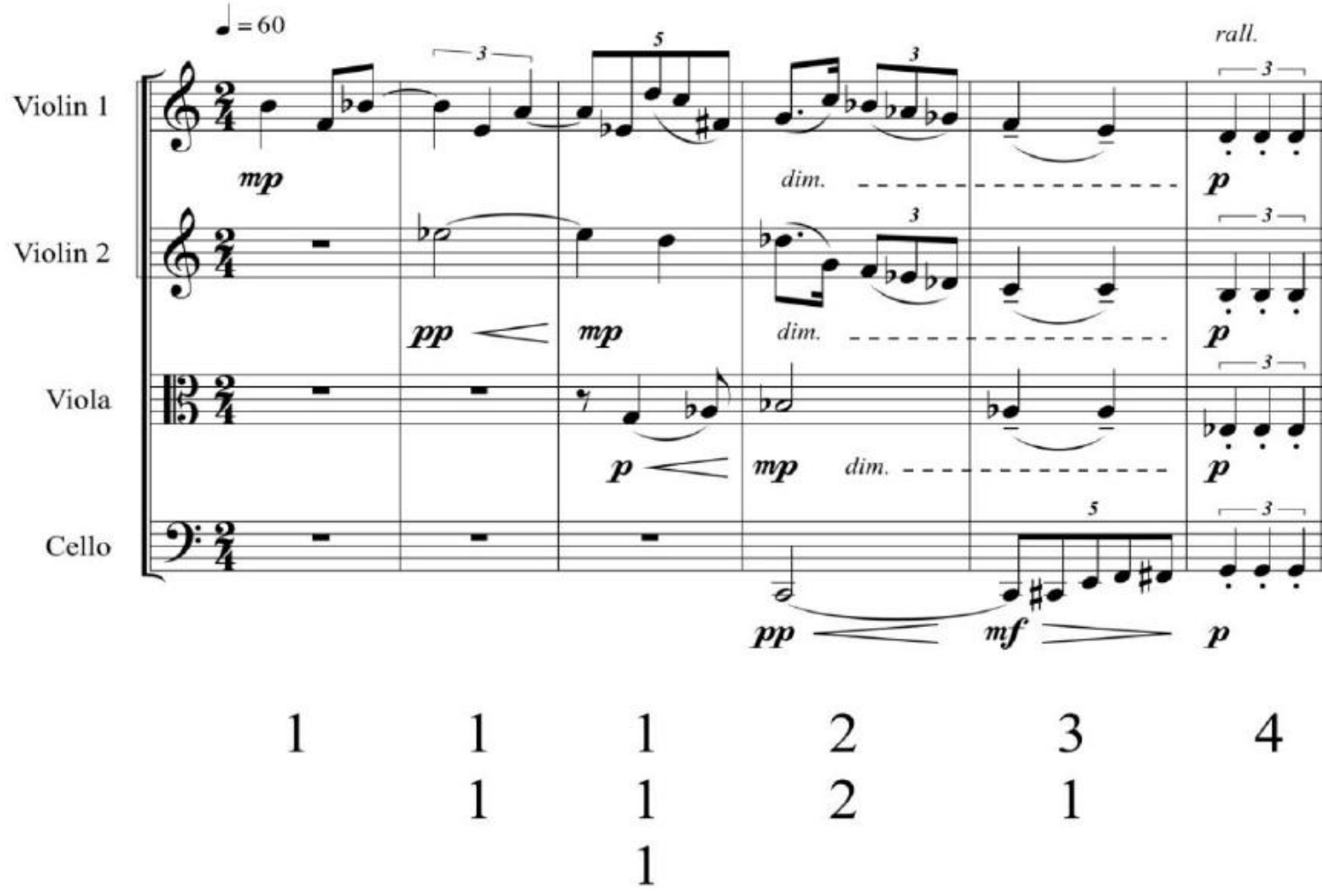

\section{Música estocástica Markoviana}

Conforme proposto por Xenakis (1992) em seu segundo capítulo, uma forma de abandonar o determinismo e incorporar elementos estocásticos na composição musical é pela utilização de cadeias de Markov. Tal estrutura matemática é um bom equilíbrio entre a simplicidade e a manutenção de determinada estrutura interna a fim de manter uma coerência desejada, em vez da utilização de elementos puramente estocásticos. Com efeito, na literatura corrente as cadeias de Markov têm sido amplamente utilizadas para composição algorítmica, em particular a fim de mimetizar informaçóes contidas em um corpus ou reproduzir certa informação desejada (MAIA, 2016).

Denote por $Z=\left\{x_{1}, \ldots, x_{n}\right\}$ um conjunto de interesse, cujos elementos chamaremos de estados, e sejam $X_{1}, X_{2}, \ldots$ uma sequência de variáveis quantitativas, que denominaremos variáveis aleatórias, cujos valores são elementos do conjunto $Z$, porém sua especificidade depende de fatores aleatórios. Dizemos que essa sequência de variáveis aleatórias forma uma cadeia de Markov se, conforme MEDEIROS et al (2011, p. 1880) definem, “a probabilidade de ocorrência de um evento 
FERREIRA, Esdras Sarmento; SANTOS, Raphael Sousa; LIMA, Flávio Fernandes de; CARVALHO, Hugo Tremonte de; PITOMBEIRA, Liduino. Sistema Composicional Intermarkoviano. Revista Vórtex, Curitiba, v.8, n.2, p. 1-46, 2020.

não depende de todo o passado, mas apenas do evento imediatamente anterior”25. Na linguagem usual de Teoria de Probabilidades, podemos descrever isso na equação $P\left(X_{n}=x \mid X_{n-1}=\right.$ $\left.y, \ldots, X_{1}=z\right)=P\left(X_{n}=x \mid X_{n-1}=y\right)$.

Associada a uma cadeia de Markov, podemos construir a sua matriz de transição de probabilidades, uma tabela com $n$ linhas e $n$ colunas de modo que o número na linha $i$ e coluna $j$ representa a probabilidade de saltar para o estado $x_{j}$ estando-se no estado $x_{i}$. A fim de ilustração, a Figura 15 mostra a representação visual de uma cadeia de Markov com estados no conjunto $Z=$ $\{A, B, C\}$ e sua respectiva matriz de transição de probabilidades.

FIGURA 15 - Cadeia de Markov de três estados e sua matriz de transição de probabilidades.
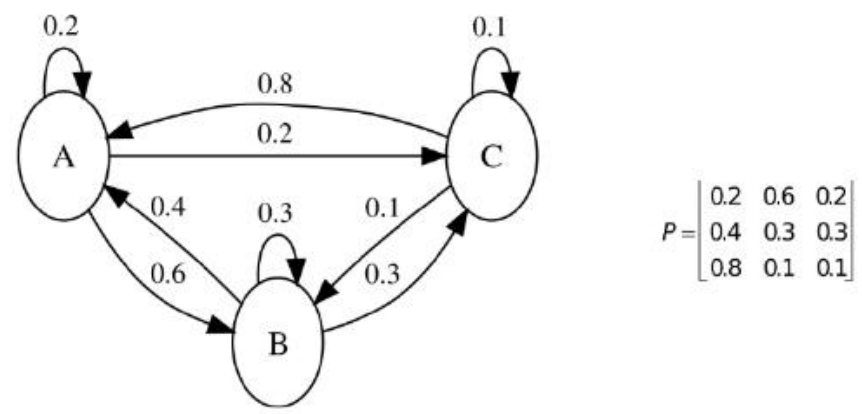

Para o compositor que deseja utilizar tal ferramenta, é de especial interesse a natureza musical dos estados, de modo a determinar se a estrutura markoviana será imposta nas alturas, duraçóes, dinâmicas ou na combinação de vários parâmetros de interesse (AMES, 1989, p. 181 e CHAI e VERCOE, 2001, p. 2). No capítulo III, XENAKIS (1992) propõe um arcabouço bastante geral através do conceito de telas, essencialmente uma representação tempo-frequência de um som, onde um determinado instante de tempo fixo pode ser visto como uma imagem bidimensional, com um eixo representando as frequências sendo executadas naquele instante e o outro eixo contendo as respectivas intensidades. Tal objeto é bastante interessante, porém devido à sua generalidade é demasiado complexo para ser manipulado diretamente, conforme apontado pelo próprio autor, onde é apresentada uma estratégia alternativa no processo composicional das obras Analogique $A$ e

\footnotetext{
${ }^{25}$ A definição feita nesse texto é de caráter menos geral da usualmente empregada em textos de Matemática. De fato, a estrutura aqui definida, a rigor, chama-se "cadeia de Markov homogênea a tempo discreto e espaço de estados finito", porém a chamaremos somente "cadeia de Markov" por razões de simplicidade. O leitor interessado em tais generalizações poderá consultar MAIA (2016).
} 
FERREIRA, Esdras Sarmento; SANTOS, Raphael Sousa; LIMA, Flávio Fernandes de; CARVALHO, Hugo Tremonte de; PITOMBEIRA, Liduino. Sistema Composicional Intermarkoviano. Revista Vórtex, Curitiba, v.8, n.2, p. 1-46, 2020.

Analogique B. É importante ressaltar, porém, que mesmo não utilizadas dessa forma para tarefas composicionais, as telas de Xenakis marcam o nascimento da síntese granular (ROADS, 1996).

O estudo teórico das cadeias de Markov, do ponto de vista da Teoria das Probabilidades, assume que a matriz de transição de probabilidades é conhecida a priori. Porém, quando empregada como ferramenta de geração de novo material musical apresentam-se duas possibilidades: fixar a matriz de transição de probabilidades a fim de criar um efeito sonoro ou estilístico desejado pelo compositor, ou estimá-la a partir de um corpus de interesse a fim de reproduzir estruturas lá contidas. Neste trabalho o maior interesse é no segundo aspecto, e Lucas Maia (2016) apresenta uma discussão mais aprofundada sobre tais procedimentos de estimação ${ }^{26}$. Aqui será suficiente definirmos um objeto auxiliar, denominado matriz de contagem de transiçôes, cujo elemento na linha $i$ e coluna $j$ contém quantas vezes transita-se do estado $x_{i}$ para o estado $x_{j}$ no corpus de interesse. A partir de tal matriz é imediato construir uma matriz de transição de probabilidades, dividindo cada linha pela soma de seus elementos, porém a formulação em termos da matriz de contagem de transições é mais conveniente para uso no aplicativo Markov Model, descrito na próxima Seção.

\section{Sistema Composicional Intermarkoviano}

O Sistema Composicional Intermakoviano utiliza estados markovianos de uma obra original, um intertexto. No caso específico deste trabalho, esses estados são oriundos de duas fontes: os contornos melódicos e relações de interdependência textural. Mais especificamente, em uma primeira fase modelamos um intertexto pela determinação de aspectos quantitativos relacionados aos contornos melódicos e à interdependência textural, produzindo matrizes de transição específicas para cada um desses aspectos; na segunda fase, os dados referentes a essa modelagem são alimentados no aplicativo computacional Markov Model $^{27}$ que fornece novos contornos e novas relaçóes de

\footnotetext{
${ }^{26}$ Em MAIA (2016) é apresentado brevemente um apanhado de técnicas para estimação de probabilidades de transição de cadeias de Markov a partir de um corpus de obras modeladas por tal objeto matemático. Os exemplos lá apresentados consideram os estados como notas ou acordes, essencialmente, porém a teoria estatística é mais geral e se aplica a qualquer conjunto de estados, desde que finito. Dessa forma, o sistema aqui proposto tem como uma de suas fundamentações, do ponto de vista estatístico, o trabalho de MAIA. No entanto, em termos específicos o trabalho de MAIA não apresenta experimentos com contornos ou partições texturais sendo uma abordagem original deste trabalho.

${ }^{27}$ Disponível em https://gitlab.com/gamag/markovmodel/-/releases
} 
FERREIRA, Esdras Sarmento; SANTOS, Raphael Sousa; LIMA, Flávio Fernandes de; CARVALHO, Hugo Tremonte de; PITOMBEIRA, Liduino. Sistema Composicional Intermarkoviano. Revista Vórtex, Curitiba, v.8, n.2, p. 1-46, 2020.

interdependência textural, as quais guardam, até primeira ordem ${ }^{28}$, as mesmas relações sintáticas com o intertexto, algo que nos é garantido pelas propriedades inerentes de uma cadeia de Markov.

O aplicativo Markov Model (SANTOS, 2012), programado em Java especificamente para esta pesquisa, recebe em sua tela principal dados no seguinte formato: $[x][y] q$, onde $x$ é um valor inicial (em qualquer formato: número inteiro, texto, símbolo etc.), $y$ um valor imediatamente subsequente, e q, a quantidade de vezes que $x$ é seguido por $y$. Tomemos como exemplo, as alturas e duraçóes (sem informaçốes de articulaçóes e dinâmicas) dos quatro compassos iniciais da Sonata para Piano no. 16 'Facile', K. 545, de W. A. Mozart (Figura 16). Consideremos as alturas do trecho como classes de alturas, ou seja, alturas sem registro, e construamos a matriz de transição de probabilidades para o trecho, mostrada na Tabela 4. Nessa tabela, observa-se, em sintonia com o que acontece no trecho de Mozart, que a classe de altura Dó é seguida uma única vez pelas classes de alturas Ré, Mi e Sol. Portanto, se, partindo dessa tabela, realizarmos um sorteio, o Dó tem $1 / 3$ de probabilidade de ir para o Ré, $1 / 3$ de probabilidade de ir para o Mi e, finalmente, $1 / 3$ de probabilidade de ir para o Sol. Por sua vez, o Fá tem $100 \%$ de chance de ir para o Mi. Se alimentarmos as informações da Tabela 4 na tela principal do aplicativo (Figura 17), selecionarmos a quantidade de novos valores a serem gerados (dez, na Figura 17) e pressionarmos o botão 'Gerar', produziremos na tela 'Resultado' dez valores que obedecem rigorosamente as regras probabilísticas da matriz de transição de probabilidades mostrada na Tabela 4. O primeiro valor é escolhido uniformemente dentre as possibilidades apresentadas ao aplicativo. Como somente os valores referentes às classes de altura foram introduzidos no aplicativo, os resultados obviamente não vislumbram nenhuma informação rítmica, ficando essa a cargo da livre escolha do compositor. Conforme se observa na Figura 18, associamos livremente valores rítmicos às classes de alturas geradas pelo aplicativo e representamos o resultado em notação musical.

\footnotetext{
${ }^{28}$ Seria possível obter estruturas de ordem superior se alterássemos a definição de cadeia de Markov para que a probabilidade de ocorrência de um evento não dependa de todo o passado, mas sim dos $k$ eventos imediatamente anteriores, para valores de $k$ maiores que ou iguais a 2. Apesar de tal abordagem mostrar-se mais eficaz na reprodutibilidade da informação de interesse, ela pode apresentar certas dificuldades no âmbito estatístico sobre a estimação da matriz de transição de probabilidades, bem como um elevado valor de $k$ pode implicar não na criação de novo material musical mas sim apenas em réplicas exatas de trechos contidos no corpus (MAIA, 2016).
} 
FERREIRA, Esdras Sarmento; SANTOS, Raphael Sousa; LIMA, Flávio Fernandes de; CARVALHO, Hugo Tremonte de; PITOMBEIRA, Liduino. Sistema Composicional Intermarkoviano. Revista Vórtex, Curitiba, v.8, n.2, p. 1-46, 2020.

FIGURA 16 - Quatro compassos iniciais da Sonata para Piano no. 16 'Facile', K. 545, de W. A. Mozart.

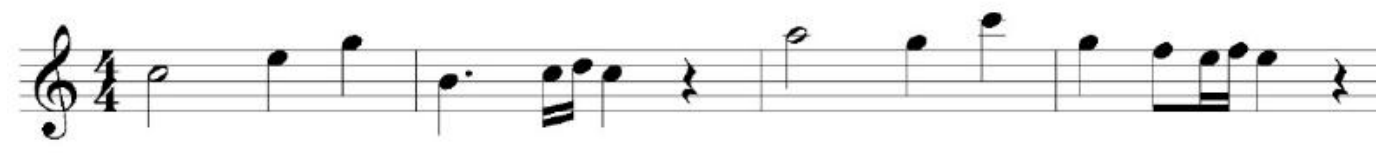

Fonte: MOZART (1986, p. 122)

TABELA 4 - Matriz de transição de probabilidades para os quatro compassos iniciais da Sonata para Piano no. 16 'Facile', K. 545, de W. A. Mozart.

\begin{tabular}{|l|l|l|l|l|l|l|l|}
\cline { 2 - 8 } \multicolumn{1}{c|}{} & Dó & Ré & Mi & Fá & Sol & Lá & Si \\
\hline Dó & 0 & $1 / 3$ & $1 / 3$ & 0 & $1 / 3$ & 0 & 0 \\
\hline Ré & 1 & 0 & 0 & 0 & 0 & 0 & 0 \\
\hline Mi & 0 & 0 & 0 & $1 / 2$ & $1 / 2$ & 0 & 0 \\
\hline Fá & 0 & 0 & 1 & 0 & 0 & 0 & 0 \\
\hline Sol & $1 / 3$ & 0 & 0 & $1 / 3$ & 0 & 0 & $1 / 3$ \\
\hline Lá & 0 & 0 & 0 & 0 & 1 & 0 & 0 \\
\hline Si & 1 & 0 & 0 & 0 & 0 & 0 & 0 \\
\hline
\end{tabular}

FIGURA 17 - Aplicativo Markov Model. Na tela inferior (à esquerda) os caminhos das classes de alturas dos quatro compassos iniciais da Sonata para Piano no. 16 'Facile', K. 545, de W. A. Mozart são inseridos. Na tela superior (Resultado) uma nova linha com dez alturas é gerada. Essa nova linha segue o mesmo perfil markoviano da melodia original.

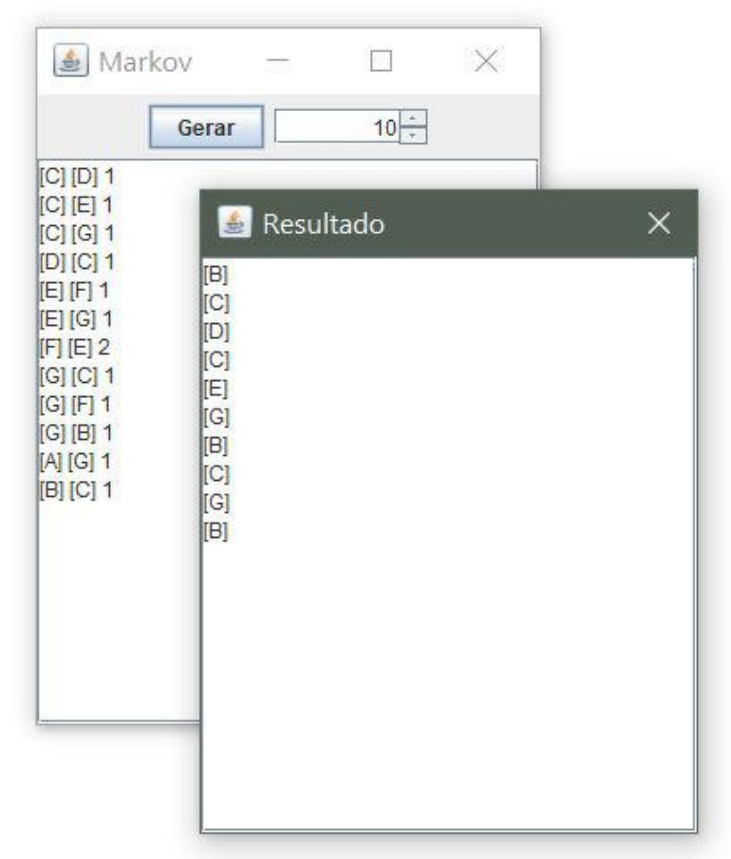


FERREIRA, Esdras Sarmento; SANTOS, Raphael Sousa; LIMA, Flávio Fernandes de; CARVALHO, Hugo Tremonte de; PITOMBEIRA, Liduino. Sistema Composicional Intermarkoviano. Revista Vórtex, Curitiba, v.8, n.2, p. 1-46, 2020.

FIGURA 18 - Novo fragmento gerado a partir da matriz de transição de probabilidades dos quatro compassos iniciais da Sonata para Piano no. 16 'Facile', K. 545, de W. A. Mozart.

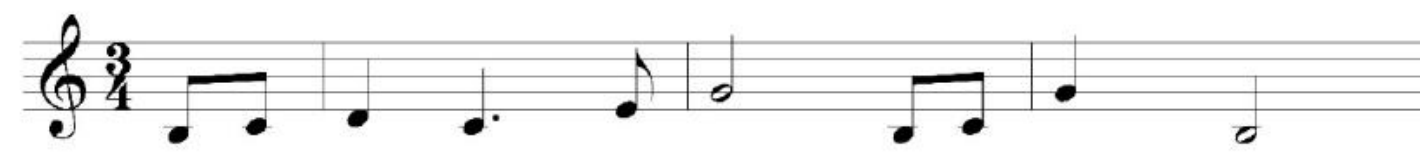

A Figura 19 mostra o inteiro segundo movimento dos Cinco Movimentos para Quarteto de Cordas Op. 5, de Webern. A obra pode ser articulada em três seções: A B A'. A seção A se divide em duas subseçốes. Na primeira subseção, a1 (c.1-4), uma linha melódica executada pela viola é acompanhada por acordes de quatro e, posteriormente, de três notas executadas pelo segundo violino e pelo violoncelo. Essa subseção se encerra com um diálogo contrapontístico entre viola e violoncelo que culmina em um acorde em pizzicato. A subseção a2 (c.5-6) retoma a textura homofônica inicial, com a melodia sendo executada pelo segundo violino e os acordes pela viola e pelo violoncelo. A seção B (c.7-9) se inicia com o eco defasado de um gesto proposto pelo primeiro violino e, em seguida, se desenvolve uma textura constituída por uma melodia (executada pelo primeiro violino) acompanhada de um ostinato (executado pelo segundo violino), com breves intervenções da viola e do violoncelo. Finalmente, a seção A' (c.10-13) retoma com acordes (executados pela viola e pelo violoncelo) que acompanham uma melodia executada pelo primeiro violino e, em seguida, pelo segundo violino. Os dois últimos compassos funcionam como uma coda. A estrutura A B A' está indicada em vermelho na Figura 19.

Na mesma Figura 19 também indicamos uma possível segmentação de contornos melódicos. Não entram nessa segmentação os acordes, o ostinato e as pequenas intervençóes (como o pizzicato do violoncelo no c.10 ou o dobramento em oitava do segundo violino no c.5). A Tabela 5 consiste, na verdade, de duas partes. No lado esquerdo temos os 22 contornos melódicos identificados na Figura 19; no lado direito temos a matriz de contagem de transições entre os 11 contornos distintos. O último contorno é artificialmente induzido a ir uniformemente para qualquer um dos contornos para que o sorteio não seja interrompido caso ele seja escolhido durante o processo. Os dados da matriz de contagem de transições da Tabela 2 são inseridos no aplicativo Markov Model gerando 25 novos contornos melódicos (tela 'Resultado’ da Figura 20). 
FERREIRA, Esdras Sarmento; SANTOS, Raphael Sousa; LIMA, Flávio Fernandes de; CARVALHO, Hugo Tremonte de; PITOMBEIRA, Liduino. Sistema Composicional Intermarkoviano. Revista Vórtex, Curitiba, v.8, n.2, p. 1-46, 2020.

TABELA 5 - Os 22 contornos melódicos identificados na Figura 8 (esquerda) e matriz de contagem de transições (direita) para os 11 contornos distintos do segundo movimento dos Cinco Movimentos para Quarteto de Cordas, Op. 5, de Webern.

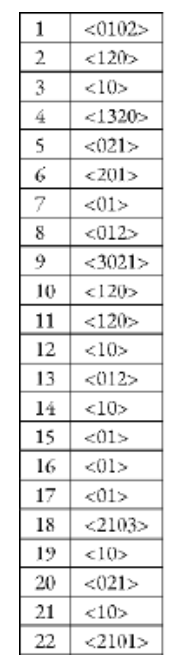

\begin{tabular}{|l|l|l|l|l|l|l|l|l|l|l|l|l|}
\cline { 2 - 14 } \multicolumn{2}{c|}{} & 1 & 2 & 3 & 4 & 5 & 6 & 7 & 8 & 9 & 10 & 11 \\
\cline { 2 - 15 } \multicolumn{2}{c|}{} & $\langle 0102\rangle$ & $\langle 120\rangle$ & $\langle 10\rangle$ & $\langle 1320\rangle$ & $\langle 021\rangle$ & $\langle 201\rangle$ & $\langle 01\rangle$ & $\langle 012\rangle$ & $\langle 3021\rangle$ & $\langle 2103\rangle$ & $\langle 2101\rangle$ \\
\hline 1 & $\langle 0102\rangle$ & 0 & 1 & 0 & 0 & 0 & 0 & 0 & 0 & 0 & 0 & 0 \\
\hline 2 & $\langle 120\rangle$ & 0 & 1 & 2 & 0 & 0 & 0 & 0 & 0 & 0 & 0 & 0 \\
\hline 3 & $\langle 10\rangle$ & 0 & 0 & 0 & 1 & 1 & 0 & 1 & 1 & 0 & 0 & 0 \\
\hline 4 & $\langle 1320\rangle$ & 0 & 0 & 0 & 0 & 1 & 0 & 0 & 0 & 0 & 0 & 0 \\
\hline 5 & $\langle 021\rangle$ & 0 & 0 & 1 & 0 & 0 & 1 & 0 & 0 & 0 & 0 & 0 \\
\hline 6 & $\langle 201\rangle$ & 0 & 0 & 0 & 0 & 0 & 0 & 1 & 0 & 0 & 0 & 0 \\
\hline 7 & $\langle 01\rangle$ & 0 & 0 & 0 & 0 & 0 & 0 & 2 & 1 & 0 & 1 & 0 \\
\hline 8 & $\langle 012\rangle$ & 0 & 0 & 1 & 0 & 0 & 0 & 0 & 0 & 1 & 0 & 0 \\
\hline 9 & $\langle 3021\rangle$ & 0 & 1 & 0 & 0 & 0 & 0 & 0 & 0 & 0 & 0 & 0 \\
\hline 10 & $\langle 2103\rangle$ & 0 & 0 & 1 & 0 & 0 & 0 & 0 & 0 & 0 & 0 & 0 \\
\hline 11 & $\langle 2101\rangle$ & 1 & 1 & 1 & 1 & 1 & 1 & 1 & 1 & 1 & 1 & 1 \\
\hline
\end{tabular}


FIGURA 19 - Articulação formal e contornos melódicos identificados no segundo movimento dos Cinco Movimentos para Quarteto de Cordas, Op.5, de Anton Webern.

$\mathrm{A} \mathrm{a}_{1}$

Sehr langsam $(h)=$ ca 56$)$
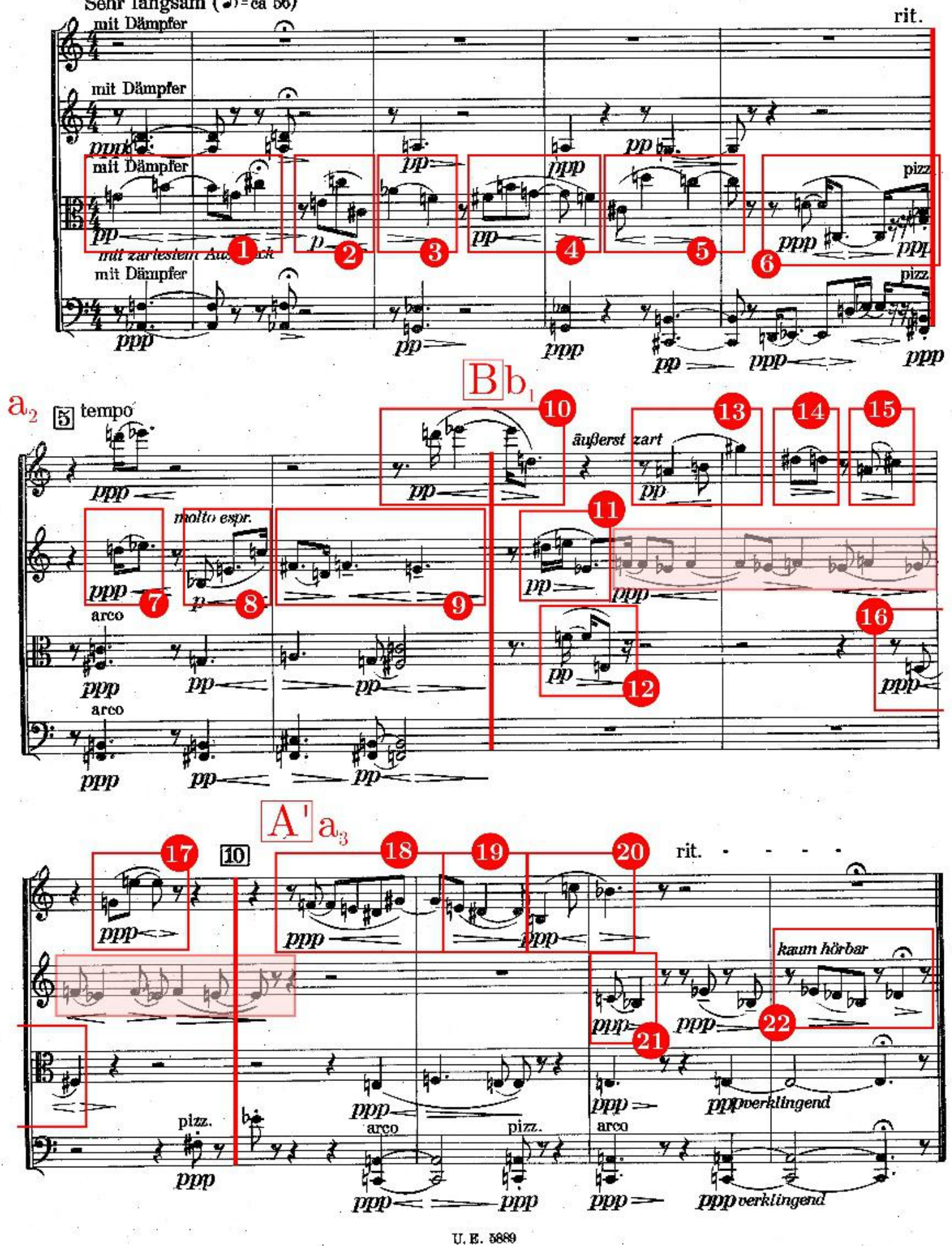

Fonte: WEBERN (1922, p. 6) 
FERREIRA, Esdras Sarmento; SANTOS, Raphael Sousa; LIMA, Flávio Fernandes de; CARVALHO, Hugo Tremonte de; PITOMBEIRA, Liduino. Sistema Composicional Intermarkoviano. Revista Vórtex, Curitiba, v.8, n.2, p. 1-46, 2020.

FIGURA 20 - Interface gráfica de usuário do aplicativo Markov Model mostrando na tela principal (lado esquerdo) os contornos melódicos identificados no segundo movimento dos Cinco Movimentos para Quarteto de Cordas, Op.5, de Anton Webern, e, na tela resultado (lado direito), 25 contornos gerados pelo aplicativo com base na matriz de transição de probabilidades da obra original.

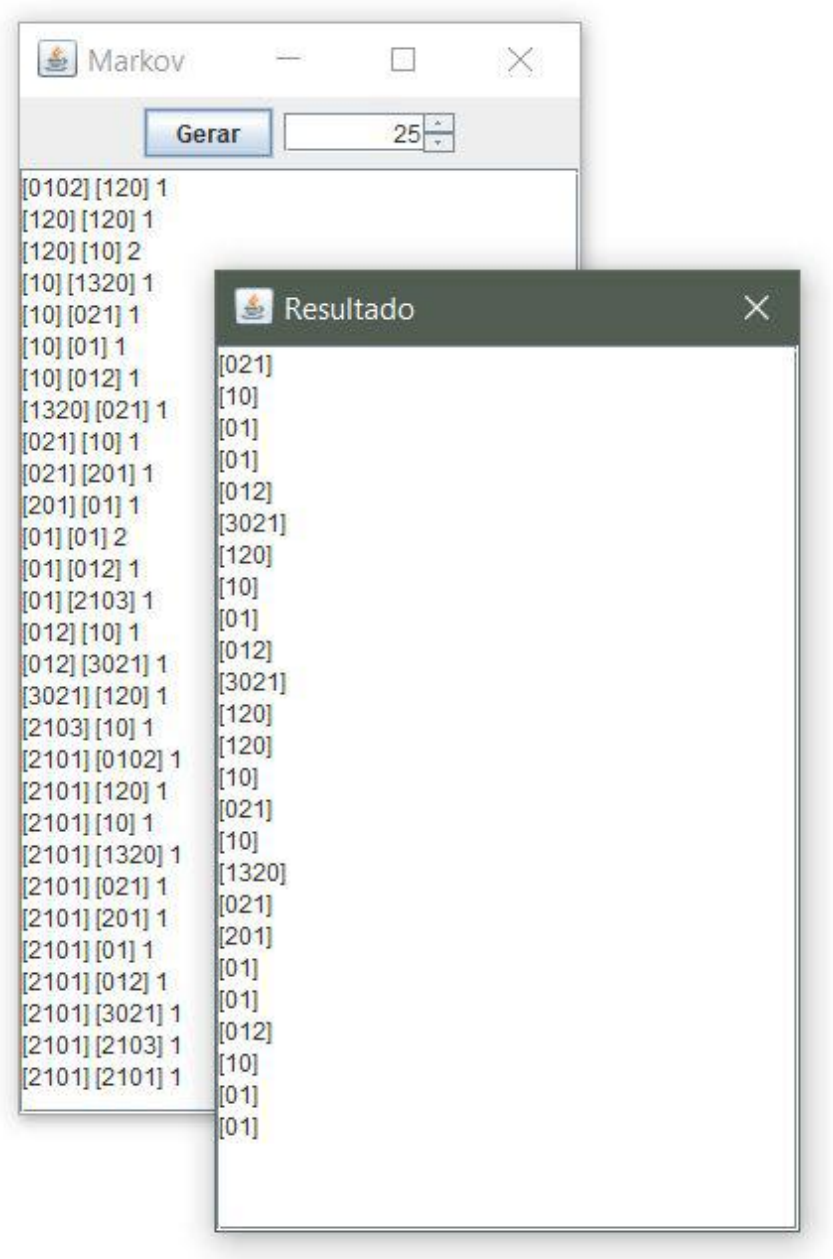

Em seguida, realizamos a análise das partições texturais rítmicas da obra de Webern (Figura 21) e, da mesma forma que fizemos com os contornos melódicos, produzimos uma matriz de transição de probabilidades para essas partiçôes. As partições são indicadas a cada novo ponto de ataque de qualquer uma das partes instrumentais e o silêncio é indicado como partição 0 . As partes de uma partição são separadas por pontos, e valores particionais idênticos (1.1.1) são resumidos na notação abreviada exponencial $\left(1^{3}\right)$. Os caminhos entre as doze partições texturais rítmicas distintas encontradas no quarteto de Webern nos permitiram produzir uma matriz de contagem de transiçóes (Tabela 6). A partir dessa matriz geramos uma nova sequência de 55 partiçóes com o auxílio do Markov Model (Figura 22). 
FIGURA 21 - Partiçóes texturais identificadas no segundo movimento dos Cinco Movimentos para Quarteto de Cordas, Op.5, de Anton Webern.

Sehr langsam $(h)$ ca 56$)$

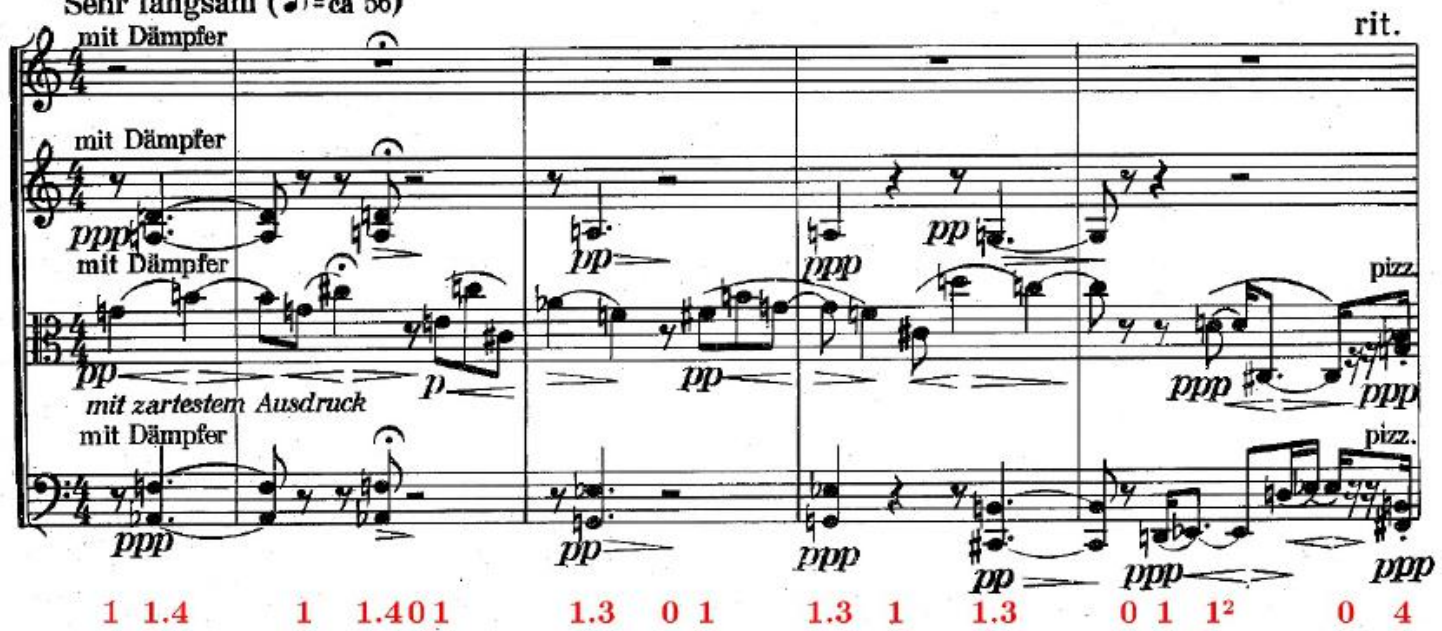

[5 tempo

$\begin{array}{llll}1 & 1.4 & 1 & 1.401\end{array}$

$\begin{array}{lll}.3 & 0 & 1\end{array}$

$\begin{array}{lll}1.3 & 1 & 1.3\end{array}$

$\begin{array}{lll}0 & 1 & 1^{2}\end{array}$

4

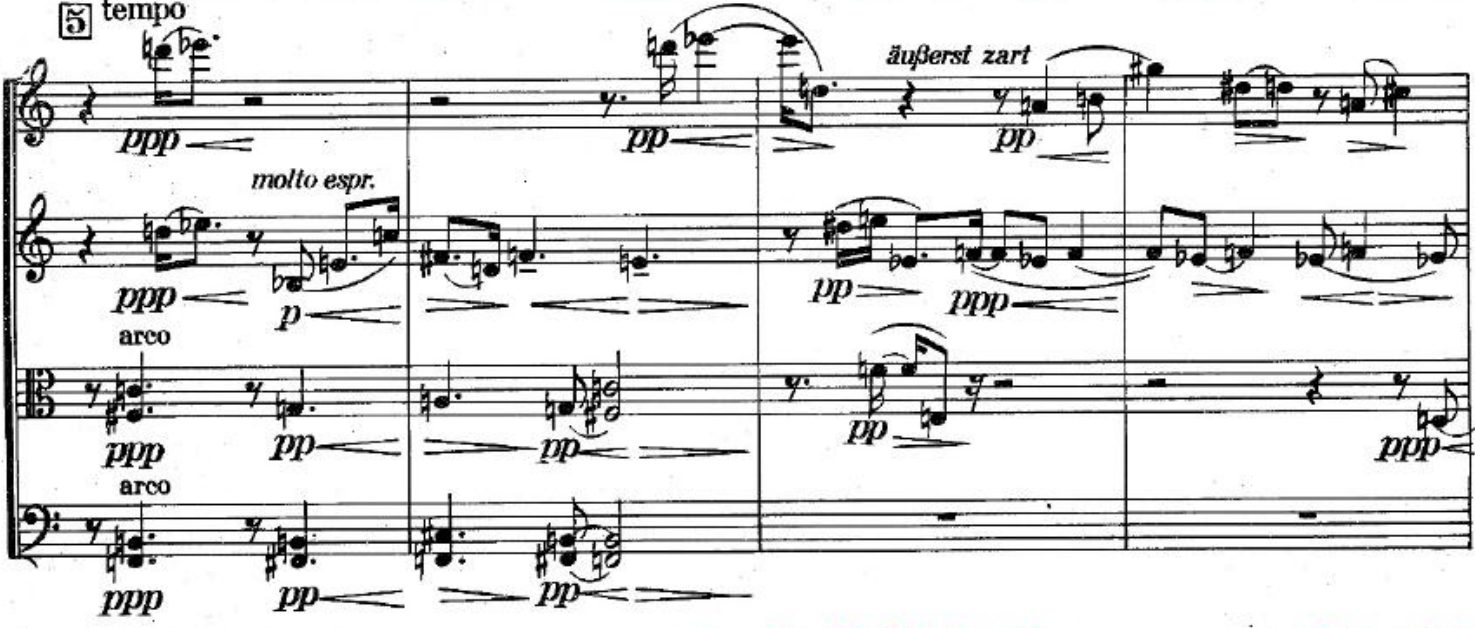

$\begin{array}{lllll}0 & 4 & 2.4 & 0 & 1.3\end{array}$

$1.44 .1^{2} \quad 1.1^{2} 1^{3} 1^{2} \quad 1 \quad 1^{2}$

$11^{2}$

2.1

[10]

rit.

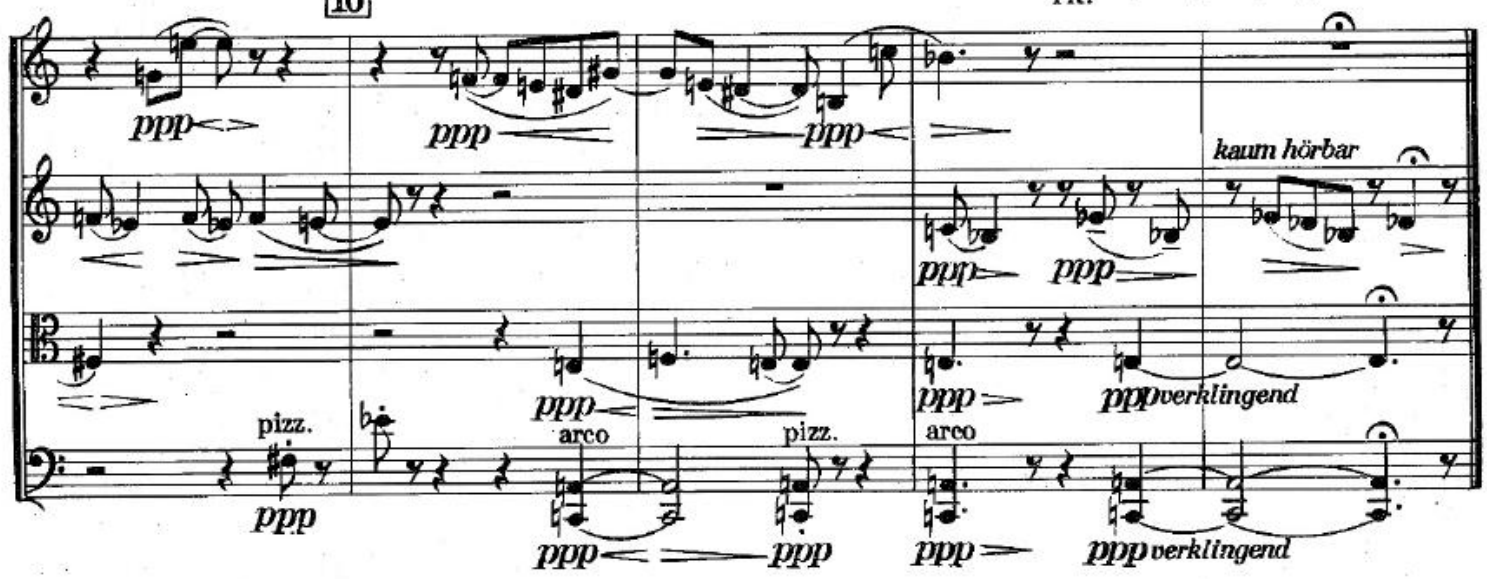

$1^{2}$

$\begin{array}{lllll}11^{2} & 1 & 1^{2} & 0 & 1\end{array}$

$2.1^{2}$

1.4

$\begin{array}{llll}0 & 1 & 3 & 1.3\end{array}$

31.3

31.30

Fonte: WEBERN (1922, p. 6) 
FERREIRA, Esdras Sarmento; SANTOS, Raphael Sousa; LIMA, Flávio Fernandes de; CARVALHO, Hugo Tremonte de; PITOMBEIRA, Liduino. Sistema Composicional Intermarkoviano. Revista Vórtex, Curitiba, v.8, n.2, p. 1-46, 2020.

FIGURA 22 - Interface gráfica de usuário do aplicativo Markov Model mostrando na tela principal (lado esquerdo) as partições texturais rítmicas identificadas no segundo movimento dos Cinco Movimentos para Quarteto de Cordas, Op.5, de Anton Webern, e, na tela Resultado (lado direito), 55 novas partiçóes geradas pelo aplicativo com base na matriz de transição de probabilidades da obra original (Tabela 3).

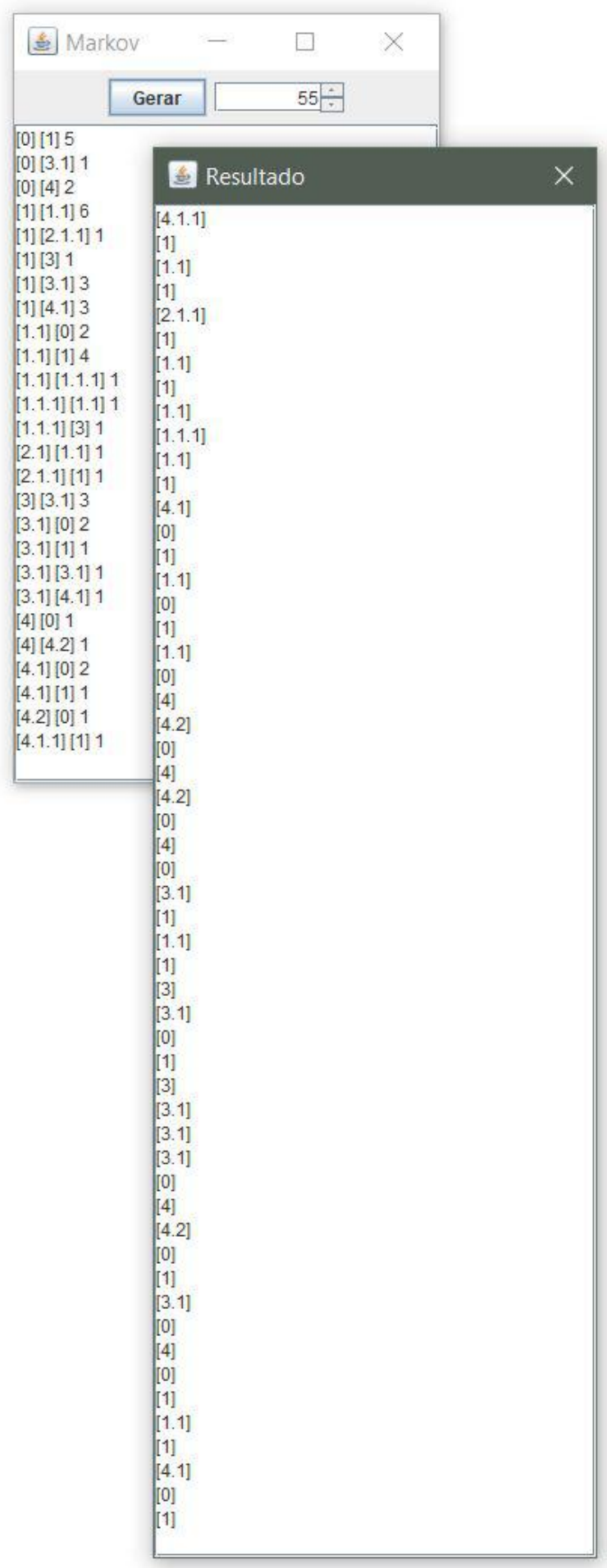


FERREIRA, Esdras Sarmento; SANTOS, Raphael Sousa; LIMA, Flávio Fernandes de; CARVALHO, Hugo Tremonte de; PITOMBEIRA, Liduino. Sistema Composicional Intermarkoviano. Revista Vórtex, Curitiba, v.8, n.2, p. 1-46, 2020.

TABELA 6 - Matriz de contagem de transições das doze partições texturais rítmicas identificadas no segundo movimento dos Cinco Movimentos para Quarteto de Cordas, Op. 5, de Webern.

\begin{tabular}{|l|l|l|l|l|l|l|l|l|l|l|l|l|}
\cline { 2 - 13 } \multicolumn{1}{c|}{} & 0 & 1 & $1^{2}$ & $1^{3}$ & 2.1 & $2.1^{2}$ & 3 & 3.1 & 4 & 4.1 & 4.2 & $4.1^{2}$ \\
\hline 0 & 0 & 5 & 0 & 0 & 0 & 0 & 0 & 1 & 2 & 0 & 0 & 0 \\
\hline 1 & 0 & 0 & 6 & 0 & 0 & 1 & 1 & 3 & 0 & 3 & 0 & 0 \\
\hline $1^{2}$ & 2 & 4 & 0 & 1 & 0 & 0 & 0 & 0 & 0 & 0 & 0 & 0 \\
\hline $1^{3}$ & 0 & 0 & 1 & 0 & 0 & 0 & 1 & 0 & 0 & 0 & 0 & 0 \\
\hline 2.1 & 0 & 0 & 1 & 0 & 0 & 0 & 0 & 0 & 0 & 0 & 0 & 0 \\
\hline $2.1^{2}$ & 0 & 1 & 0 & 0 & 0 & 0 & 0 & 0 & 0 & 0 & 0 & 0 \\
\hline 3 & 0 & 0 & 0 & 0 & 0 & 0 & 0 & 3 & 0 & 0 & 0 & 0 \\
\hline 3.1 & 2 & 1 & 0 & 0 & 0 & 0 & 0 & 1 & 0 & 1 & 0 & 0 \\
\hline 4 & 1 & 0 & 0 & 0 & 0 & 0 & 0 & 0 & 0 & 0 & 1 & 0 \\
\hline 4.1 & 2 & 1 & 0 & 0 & 0 & 0 & 0 & 0 & 0 & 0 & 0 & 0 \\
\hline 4.2 & 1 & 0 & 0 & 0 & 0 & 0 & 0 & 0 & 0 & 0 & 0 & 0 \\
\hline $4.1^{2}$ & 0 & 1 & 0 & 0 & 0 & 0 & 0 & 0 & 0 & 0 & 0 & 0 \\
\hline
\end{tabular}

Em termos das tipologias mencionadas na seção inicial deste artigo, o sistema aqui proposto é modelado e tem uma característica majoritariamente semiaberta, uma vez que só fornece informações de saída, embora sua configuração interna dependa de uma preparação que é efetivada a partir de um texto musical externo. Preparada essa configuração interna do sistema (um preset, digamos assim), a escolha do estado inicial, ou mais geralmente a distribuição de probabilidade do estado inicial, pode ser feita de modo a independer da escolha do usuário. Vale salientar, contudo, que o processo de geração de uma sequência markoviana depende de uma retroalimentação, exceto no caso de ordem zero. Porém, tal retroalimentação representa um aspecto mais interno do sistema, não dependendo de intervenção do usuário. A retroalimentação é uma característica inerente à cadeia de Markov: para gerar o próximo estado, deve se ter conhecimento do último estado produzido.

Desta forma, a obra musical original (intertexto) utilizada para preparar o sistema nos estados iniciais não deve ser interpretada como a entrada de um sistema aberto, uma vez que esse precisa de um input para funcionar, similarmente a uma função $f$ que precisa de uma variável $x$ para produzir $f(x)$ na saída. A estimação de uma matriz de transição a partir de um corpus não deve interpretada, portanto, como uma entrada do sistema, mas sim como uma configuração de arquitetura. 
FERREIRA, Esdras Sarmento; SANTOS, Raphael Sousa; LIMA, Flávio Fernandes de; CARVALHO, Hugo Tremonte de; PITOMBEIRA, Liduino. Sistema Composicional Intermarkoviano. Revista Vórtex, Curitiba, v.8, n.2, p. 1-46, 2020.

\section{Planejamento composicional do primeiro movimento de Plate Two: Érebo}

O primeiro movimento de Plate Two: Érebo, intitulado Infinito, para corne inglês e trio de cordas (violino, viola e violoncelo), de Liduino Pitombeira, foi produzido pela disposição dos contornos melódicos e das partiçóes texturais mostradas nas Figuras 20 e 22, no âmbito da escala octatônica Dó, Dó\#, Ré\#, Mi, Fá\#, Sol, Lá, Sib. Essa escala foi livremente escolhida como ponto de partida para as alturas, tendo em vista que os únicos dados disponíveis para iniciar o planejamento da obra são 25 contornos e 55 partições texturais. Os contornos, como mencionamos anteriormente (Seção 3) podem ser aplicados a diversos parâmetros, mas nos limitaremos à aplicação destes elementos somente no campo das alturas.

O processo de aplicação dos contornos às alturas, de maneira que não haja contradição com as partiçóes texturais, é minucioso e empírico. Durante o processo o compositor pode experimentar com solfejo (ou ao piano) diversas possibilidades de alturas e ritmos, tendo sempre em mente os fatores de restrição: os contornos e as partições. Após diversas tentativas, chegamos à partitura mostrada na Figura 23. O ritmo, as articulações, as dinâmicas, os andamentos e a métrica foram livremente escolhidos pelo compositor, tendo como únicas restriçốes os contornos dos gestos formadores de uma linha melódica (que flui livremente entre os instrumentos), as relações de interdependência rítmica (controladas pelas partiçóes), ao nível de ponto de ataque, e a escala de alturas.

A forma também não foi previamente definida, sendo o resultado natural do gerenciamento dos contornos e das partições texturais. Como os valores gerados têm quantidades diferentes (25 contornos melódicos e 55 partições texturais), o movimento se encerra ao final das partiçôes, sendo o repositório de contornos reiniciado para completar o ciclo melódico. Observamos na partitura de Infinito (Figura 23), a baixa recorrência de materiais temáticos, o que nos permite vislumbrar uma estrutura formada pela concatenação de quatro blocos formais distintos: A, B, C e D. As articulações formais se processam de diversas maneiras. O final da seção A é marcado por entradas defasadas que se esvaziam, partindo do corne inglês e descendo até o violoncelo. O final da seção B é marcado pelo crescendo de um bloco acordal. Entre a seção C e D há uma fermata, que indica clara divisão formal. A coda rememora de maneira flexível dois gestos importantes na obra: polifonias com entradas defasadas e blocos acordais. 
FERREIRA, Esdras Sarmento; SANTOS, Raphael Sousa; LIMA, Flávio Fernandes de; CARVALHO, Hugo Tremonte de; PITOMBEIRA, Liduino. Sistema Composicional Intermarkoviano. Revista Vórtex, Curitiba, v.8, n.2, p. 1-46, 2020.

Na Figura 23 temos a aplicação dos contornos melódicos (cor vermelha, na parte superior) e das partiçôes texturais (cor azul, na parte inferior) em Infinito (primeiro movimento de Plate Two: Érebo). Os retângulos com moldura verde indicam blocos acordais necessários para realizar as partiçóes texturais. Os retângulos verdes transparentes, sem moldura, são duplicações de contornos melódicos, também por razões texturais. Nos compassos 11, 12 e 13 o contorno $<10>$ se replica em quatro blocos acordais. No Apêndice 1, temos a partitura integral desse movimento sem as indicaçóes analíticas.

\section{Considerações finais}

Neste trabalho, descrevemos um sistema composicional modelado a partir de uma obra préexistente. Os aspectos modelados foram unicamente contornos melódicos e partiçôes texturais, ou seja, os aspectos de superfície (alturas, durações, dinâmicas, articulações) não foram considerados na modelagem. Um aplicativo computacional, elaborado durante a pesquisa, mapeou a estrutura markoviana dos dados do modelo e gerou novo repositório de valores, a partir dos quais foi elaborado, por um dos autores, o planejamento composicional de uma nova obra, para instrumentação distinta da original.

Ao comparamos as duas obras (Figuras 21 e 23), observa-se que, embora a sonoridade expressa pelas alturas, ritmos, dinâmicas e articulações seja distinta, o nível de rarefação e as silhuetas dos gestos melódicos se assemelham bastante. Tal constatação é evidente, uma vez que as partições texturais e os contornos melódicos são os mesmos da obra original, mesmo que aplicados na nova obra em uma ordem totalmente diferente (sugerida pelo aplicativo de acordo com uma sintaxe markoviana). Portanto, esses dois fatores imprimem as mesmas características texturais e de contorno melódico na nova obra. Se, contudo, somente as relações entre os contornos e entre as partições texturais tivessem sido aplicadas $^{29}$ teríamos um resultado final bem diferente, experimento já demonstrado em ${ }^{29}$ Pela determinação de operações de contorno (inversão, retrogradação, rotação) e operações texturais
(redimensionamento, revariância e transferência). 
FERREIRA, Esdras Sarmento; SANTOS, Raphael Sousa; LIMA, Flávio Fernandes de; CARVALHO, Hugo Tremonte de; PITOMBEIRA, Liduino. Sistema Composicional Intermarkoviano. Revista Vórtex, Curitiba, v.8, n.2, p. 1-46, 2020.

Pitombeira $(2017)^{30}$. Isso corrobora a hipótese de que textura e contorno podem ser tratados, no âmbito da modelagem de sistemas composicionais, como parâmetros musicais (Pitombeira, 2018), ainda que abstratos, diferenciando-se dos parâmetros superficiais (altura, ritmo, dinâmica e articulação).

É importante salientar também que a composição assistida por computador tem nesse trabalho um objetivo dual: além de nos fornecer estruturas que poderíamos não alcançar se nos ativéssemos somente a um planejamento determinístico, tais estruturas, como nos são fornecidas pelo aplicativo computacional, podem se configurar como um desafio para que o compositor crie uma obra musicalmente coerente atendo-se fielmente aos resultados do gerador aleatório. Tal desafio, pode ser percebido incialmente como uma limitação, caso o compositor tenha a expectativa de que seu trabalho composicional será facilitado e mesmo acelerado. $\mathrm{Na}$ verdade, esse aplicativo computacional apenas facilita os cálculos markovianos: todo o trabalho de segmentação e análise dos gestos é feito manualmente e os resultados são inseridos, também manualmente, no Markov Model. No nível do planejamento e da escritura em si o trabalho também exige bastante atenção para que as restrições impostas sejam seguidas. Evidentemente, a partitura final pode passar por diversos ajustes, tendo em vista fatores como exequibilidade, agógica, e mesmo ajustes estéticos no nível de alturas e ritmos.

Um fator importante a se considerar é o número de parâmetros modelados. Se esse número for elevado (digamos, a partir de quatro), o trabalho de encaixe interrelacionado dos elementos musicais de acordo com as restrições pode se tornar impossível. É preciso sempre ter em mente que a ideia não é se aproximar, em nível de superfície musical, com a obra modelada, mas de construir uma nova obra que se aparente somente em nível profundo com ela.

Por último, do ponto de vista pedagógico, a solução de problemas composicionais é algo com que nós compositores nos defrontamos diariamente, especialmente os que lidam com o ensino da composição. Assim, poderíamos apontar que a ferramenta computacional aqui empregada pode ser

\footnotetext{
${ }^{30}$ As relações entre os objetos são mais profundas do que as relações de ordem sintática markoviana. Se optássemos por considerar as primeiras, por exemplo, nas partições texturais do sétimo compasso de Webern (Figura 10), teríamos operações de revariância sucessivamente aplicadas: $1+v$ à $1^{2}+v$ à $1^{3}-v$ à $1^{2}-v$ à $1+v$ à $1^{2}$. O modelo para esse compasso, em termos particionais, seria, portanto, $\mathrm{p} 1+\mathrm{v}$ à $\mathrm{p} 2+\mathrm{v}$ à $\mathrm{p} 3-\mathrm{v}$ à $\mathrm{p} 4-\mathrm{v}$ à $\mathrm{p} 5+\mathrm{v}$ à $\mathrm{p} 6$. Estabelecido um valor particional qualquer para a partição $1(\mathrm{p} 1)$, teríamos os resultados para as demais partiçốes dadas pelo modelo. Isso produziria partiçôes diferentes da obra de Webern, ainda que aplicados na mesma ordem.
} 
FERREIRA, Esdras Sarmento; SANTOS, Raphael Sousa; LIMA, Flávio Fernandes de; CARVALHO, Hugo Tremonte de; PITOMBEIRA, Liduino. Sistema Composicional Intermarkoviano. Revista Vórtex, Curitiba, v.8, n.2, p. 1-46, 2020.

útil também no ensino de composição ${ }^{31}$, onde o aluno em formação será confrontado com restrições léxicas e sintáticas, dentro das quais se proporá a compor algo musicalmente coerente tendo como base um cenário aleatoriamente gerado.

\footnotetext{
${ }^{31}$ Essa ferramenta foi experimentada, em sala de aula, por duas turmas da Escola de Música da UFRJ: uma de composição avançada na graduação e outra de técnicas e estéticas composicionais contemporâneos da pós-graduação. Os experimentos não se limitaram aos parâmetros aqui descritos e os resultados foram satisfatórios, uma vez que em todos os cenários testados, os alunos foram expostos a desafios composicionais cuja realização seria pouco factível sem um auxílio de geração estocástica, tanto pela dificuldade técnica de determinação dos repositórios como pelos condicionamentos inerentes ao compositor no contexto de determinados materiais.
} 
FERREIRA, Esdras Sarmento; SANTOS, Raphael Sousa; LIMA, Flávio Fernandes de; CARVALHO, Hugo Tremonte de; PITOMBEIRA, Liduino. Sistema Composicional Intermarkoviano. Revista Vórtex, Curitiba, v.8, n.2, p. 1-46, 2020.

FIGURA 23 - Aplicação dos contornos melódicos e das partições texturais em Infinito (primeiro movimento de Plate Two: Érebo).
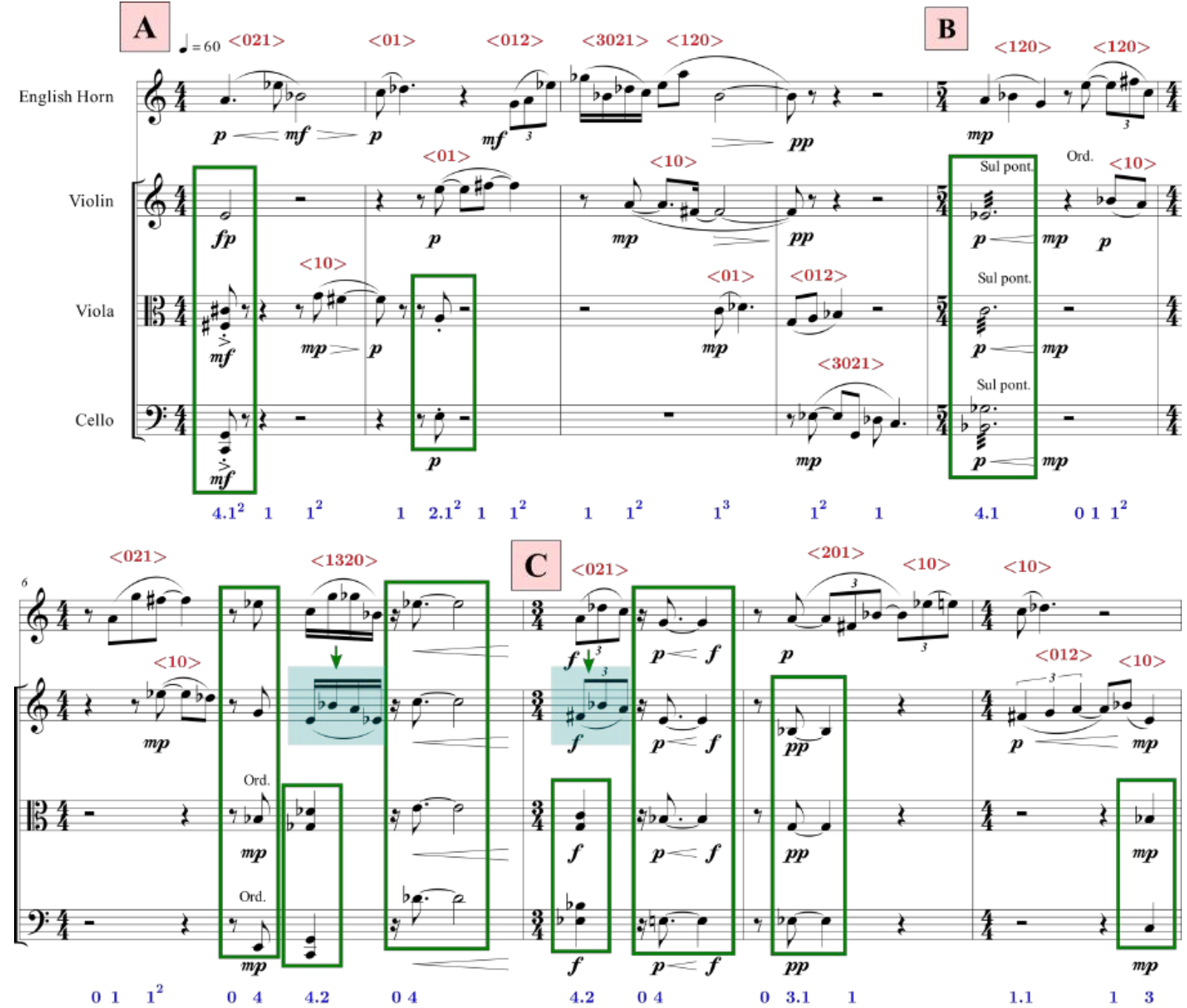

$\mathrm{D}<01><01>\quad<012>\quad$ Coda
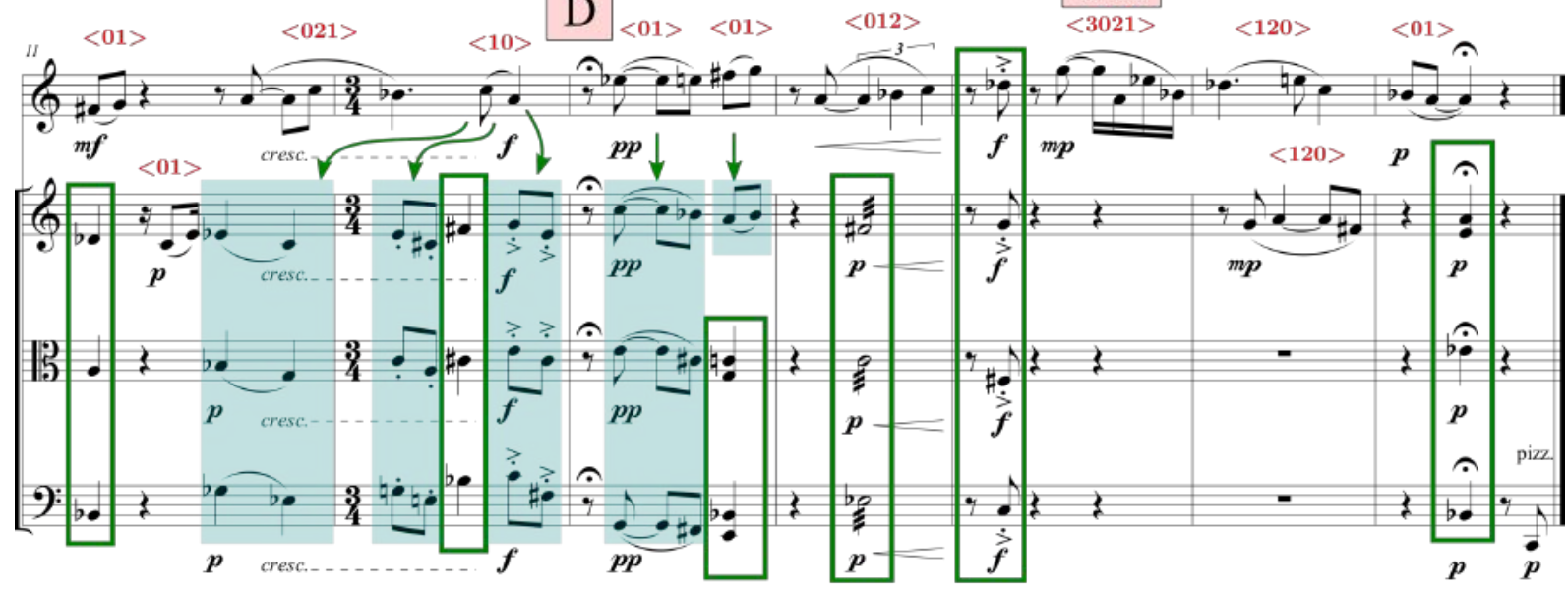

$\begin{array}{lllll}3.1 & 0 & 1 & 3 & 3.1\end{array}$

3.1

$\begin{array}{lll}3.1 & 0 & 4\end{array}$

$\begin{array}{lllll}4.2 & 0 & 1 & 3.1\end{array}$

0401

1.1

$\begin{array}{llll}1 & 4.1 & 0 & 1\end{array}$ 
FERREIRA, Esdras Sarmento; SANTOS, Raphael Sousa; LIMA, Flávio Fernandes de; CARVALHO, Hugo Tremonte de; PITOMBEIRA, Liduino. Sistema Composicional Intermarkoviano. Revista Vórtex, Curitiba, v.8, n.2, p. 1-46, 2020.

\section{REFERÊNCIAS}

AMES, Charles. The Markov Process as a Compositional Model: A Survey and Tutorial. Leonardo. v. 22, n. 2, p. 175-187, 1989.

ANDREWS, George. The theory of partitions. Cambridge: Cambridge University, 1984.

BAKHTIN, Mikhail M. The Dialogic Imagination: Four Essays. Austin: University of Texas Press, 1981.

BERRY, Wallace. Structural Functions in Music. New York: Dover Publications, 1987.

BERTALANFFY, Ludwig von. Teoria Geral dos Sistemas. Petrópolis: Vozes, 2008.

CHAI, Wei; VERCOE, Barry. Folk Music Classification Using Hidden Markov Models. Proc. of International Conference on Artificial Intelligence, 2001.

COOK, John. Solving Van der Pol equation with ivp_solve. Disponível em <https://www.johndcook.com/blog/2019/12/22/van-der-pol/>. Acesso em 21 de julho de 2020.

DOUTHETT, Jack; STEINBACH, Peter. Parsimonious Graphs: A Study in Parsimony, Contextual Transformations, and Modes of Limited Transposition. Journal of Music Theory. v. 42, n. 2, p. 241-263, 1998.

FRIEDMANN, Michael L. A Methodology for the Discussion of Contour: its Application to Schoenberg's Music. Journal of Music Theory, v.29, n.2: p. 223-48, 1985.

GENTIL-NUNES, Pauxy. Análise particional: uma mediação entre análise textural e a teoria das partiçôes. 2009. $371 \mathrm{f}$. Tese (Doutorado em Música). Centro de Letras e Artes, Universidade Federal do Estado do Rio de Janeiro. Rio de Janeiro, 2009.

GENTIL-NUNES, Pauxy. PARSEMAT - Parseme Toolbox Software Package. Rio de Janeiro: Pauxy Gentil-Nunes, 2004/2014. versão 3.8. Disponível em: http://musmat.org/downloads/ HERZOG, George. The Yuman musical style. Journal of American Folklore 41 (160), p. 183-231, 1928

KAPLAN, José Alberto. Ars inveniendi. Revista Claves. N. 01, p. 15-25, 2006.

KLEIN, Michael L. Intertextuality in Western Art Music. Bloomington: Indiana University Press, 2005.

KLIR, George. Facets of Systems Science. New York: Plenum, 1991.

KORSYN, Kevin. Toward a New Poetics of Musical Influence. Music and Analysis. v. 10, n. 1/2, p. 3-72, 1991.

KRISTEVA, Julia. Semiótica: Introdução à Semanálise. 2a. ed. São Paulo: Perspectiva, 2005.

LIMA, Flávio. Desenvolvimento de Sistemas Composicionais a partir da Intertextualidade. 2011. 239 f. Dissertação (Mestrado em Música) - UFPB. João Pessoa, 2011.

MAIA, Lucas Simões. Formalismos da Composição Algoritmica - Um Experimento com Canções Folclóricas Brasileiras. Dissertação (Mestrado em Engenharia Elétrica). Programa de Engenharia 
FERREIRA, Esdras Sarmento; SANTOS, Raphael Sousa; LIMA, Flávio Fernandes de; CARVALHO, Hugo Tremonte de; PITOMBEIRA, Liduino. Sistema Composicional Intermarkoviano. Revista Vórtex, Curitiba, v.8, n.2, p. 1-46, 2020.

Elétrica, Universidade Federal do Rio de Janeiro, Rio de Janeiro, 2016.

MALT, Mikhail. Les Mathématiques et la Composition Assistée par Ordinateur (Concepts, Outils et Modèles). Tese (Doutorado em Música e Musicologia do Século XX). Paris: Ecole des Hautes Études en Sciences Sociales, 2000.

MEDEIROS, R. J. V. ; SANTOS, R. S. ; PITOMBEIRA, Liduino . Modelagem Sistêmica baseada em Cadeias de Markov. In: XXI Congresso da ANPPOM, 2011, Uberlândia. Anais do XXI Congresso da ANPPOM, 2011.

MESQUITA, Gabriel. A acústica da influência: uma recomposição da intertextualidade na música. Rio de Janeiro, 2018. Dissertação (Mestrado em Música) - Programa de Pós-Graduação em Música, Universidade Federal do Rio de Janeiro, Rio de Janeiro, 2018.

NIEMEYER, Klaus. A Contribution to Model Theory. In: Scientific support for the decision making in the security sector. Kounchev, Ognyan; Willems, Rene; Shalamanov, Velizar; Tsachev, Tsvetomir (Ed.) (Ed.). Washington, DC : IOS Press, 2007, p.25-40.

MOZART, Wofgang. A. Sonate in C KV 545. Basel: Bärenreiter, 1986. (Partitura), 217 páginas. Piano.

MORRIS, Robert. New Directions in the Theory and Analysis of Musical Contour. Music Theory Spectrum, n. 15, n. 2, p. 205-228, 1993.

Pitombeira, Liduino. A produção de teoria composicional no Brasil. In Ilza Nogueira e Fausto Borém (org.). O pensamento musical criativo: teoria, análise e os desafios interpretativos da atualidade, 1. Salvador: Universidade Federal da Bahia, 2015, p. 61-89.

PITOMBEIRA, Liduino. Modelagem sistêmica como metodologia pré-composicional. Anais do XXVII Congresso da ANPPOM, Campinas: UNICAMP, 2017, p. 1-19.

PITOMBEIRA, Liduino. A Systemic Model for Debussy's Prélude No.1. MusMat - Brazilian Journal of Music and Mathematics. V.2, N.2, Dezembro de 2018.

PITOMBEIRA, Liduino. Compositional Systems: Overview and Applications. MusMatBrazilian Journal of Music and Mathematics. V.4, N.1, Junho de 2020.

PUFFETT, Kathryn Bailey. "Webern, Anton." Grove Music Online. 2001; Disponível em <https://www.oxfordmusiconline.com/grovemusic/view/10.1093/gmo/9781561592630.001.0001 /omo-9781561592630-e-0000029993 > . Acesso em 20 de julho de 2020.

ROADS, Curtis. The Computer Music Tutorial. Cambridge: MIT Press, 1996.

SAMPAIO, Marco da Silva. A Teoria de Relações de Contornos Musicais: Inconsistências, Soluçõese Ferramentas. Tese (Doutorado em Música). Programa de Pós-Graduação em Música, Universidade Federal da Bahia, Salvador, 2012.

SANTOS, Raphael Sousa. Markov Model. Disponível em: <https://gitlab.com/gamag/markovmodel/-/releases> . 2013.

STRAUS, Joseph N. Remaking the Past: Musical Modernism and the Influence of the Tonal Tradition. Cambridge: Harvard University Press, 1990.

STRAUS, Joseph N. Introdução à Teoria Pós-tonal. Trad.: Ricardo Bordini. Salvador: EDUFBA, 
FERREIRA, Esdras Sarmento; SANTOS, Raphael Sousa; LIMA, Flávio Fernandes de; CARVALHO, Hugo Tremonte de; PITOMBEIRA, Liduino. Sistema Composicional Intermarkoviano. Revista Vórtex, Curitiba, v.8, n.2, p. 1-46, 2020.

2013.

TENNEY, James; POLANSKY, Larry. Temporal Gestalt Perception in Music. Journal of Music Theory, v. 24, n. 2, p. 205-241, 1980

WEBERN, Anton. Fünf Sätze für Streichquartett. Wien: Universal, 1922. (Partitura), 11 páginas. Quarteto de cordas.

WEBERN, Anton. Drei kleine Stücke, Op. 11 (1914). Wien: Universal, 1952. (Partitura), 3 páginas. Violoncelo e Piano.

WEBERN, Anton. Drei Volkstexte, Op.17 (1924). Wien: Universal, 1955. (Partitura), 9 páginas. Voz, violino (ou viola), Clarinete (Si bemol) e Clarone (Si bemol).

XENAKIS, Iannis. Formalized Music: Thought and Mathematics in Music. Hillsdale: Pendragon Press, 1992.

ZAMPRONHA, Edson S. Notação, representação e composição: um novo paradigma da escritura musical. 1998. 291 f. Tese (Doutorado em Comunicação e Semiótica) - Programa de Estudos PósGraduados em Comunicação e Semiótica, Pontifícia Universidade Católica de São Paulo, São Paulo, 1998. 
FERREIRA, Esdras Sarmento; SANTOS, Raphael Sousa; LIMA, Flávio Fernandes de; CARVALHO, Hugo Tremonte de; PITOMBEIRA, Liduino. Sistema Composicional Intermarkoviano. Revista Vórtex, Curitiba, v.8, n.2, p. 1-46, 2020.

\section{SOBRE OS AUTORES}

Esdras Sarmento Ferreira é bacharel em Música, com ênfase na área de Produção musical (UFCG - 2014), tem mestrado em Música, com foco na área de Etnomusicologia (UFPB-2017) e, atualmente, cursa paralelamente a Licenciatura em Música, área de Práticas interpretativas (ênfase em Canto popular) pela Universidade Federal da Paraíba e o doutorado em Música (área de Musicologia/Etnomusicologia) pela mesma universidade. Estudou Composição musical com o compositor professor Dr. Liduino Pitombeira, Canto popular com as professoras Daniele Rezende, Sabrina Fernandes e Clara Luz, além de canto lírico com a professora Dra. Amarílis Rebuá. ORCID: https://orcid.org/0000-0002-9357-5385. E-mail: esdras_ufpb@hotmail.com

Raphael Sousa Santos é um compositor, artista visual e programador baseado na Holanda. Ele experimenta com o desenvolvimento de linguagens de programação e com o uso de processos estocásticos, algoritmos evolucionários e técnicas espectrais para a criação e performance de obras musicais e visuais. Sua área de interesse enquanto pesquisador engloba análise e síntese de áudio, teoria musical e composição assistida por computador com um foco no papel da abstração, da analogia, da manipulação sintática e do uso da linguagem durante o processo composicional ou analítico. ORCID: https://orcid.org/0000-0002-7449-3886. E-mail: contact@raphaelss.com

Flávio Fernandes de Lima é Engenheiro Químico pela Universidade Federal de Pernambuco, Bacharel em Trombone pela UFPB, Licenciado em Música pela UFPE, Pós-Graduado em Coordenação Pedagógica pela UNICAP, Mestre e Doutor em Composição Musical pela UFPB. Atual professor de Música no Instituto Federal de Pernambuco (Cursos Integrados e Pós-Graduação); Coordenador de Música no IFPE. ORCID: https://orcid.org/0000-0002-3551-3805. E-mail: flaviolima@recife.ifpe.edu.br

Hugo T. de Carvalho é Bacharel (2011) e Mestre em Matemática Aplicada (2013), e Doutor em Engenharia Elétrica (2017) pela Universidade Federal do Rio de Janeiro. Atualmente é Professor Adjunto do Departamento de Métodos Estatísticos (IM/UFRJ), e tem interesse em aplicação de métodos estatísticos em restauração de gravaçôes de áudio degradadas e recuperação de informações musicais, bem como em tópicos de Estatística Computacional. ORCID: https://orcid.org/0000-0003-0776-0400. E-mail: hugo@dme.ufrj.br

Liduino Pitombeira é professor de composição na Escola de Música da Universidade Federal do Rio de Janeiro e integra o grupo de pesquisa MusMat (PPGM-UFRJ). Suas obras têm sido executadas por diversos grupos no Brasil e no exterior, entre eles o Quinteto de Sopros da Filarmônica de Berlim e a Orquestra Sinfônica do Estado de São Paulo. Pitombeira tem Doutorado em Composição e Teoria pela Louisiana State University (EUA). Tem diversos artigos publicados em revistas e anais de congressos no Brasil. ORCID: https://orcid.org/0000-0002-1141-655X. E-mail: pitombeira@musica.ufrj.br 
APÊNDICE 1 - Partitura do primeiro movimento (Infinito) de Plate Two: Érebo, Op.255 (2020), de Liduino Pitombeira
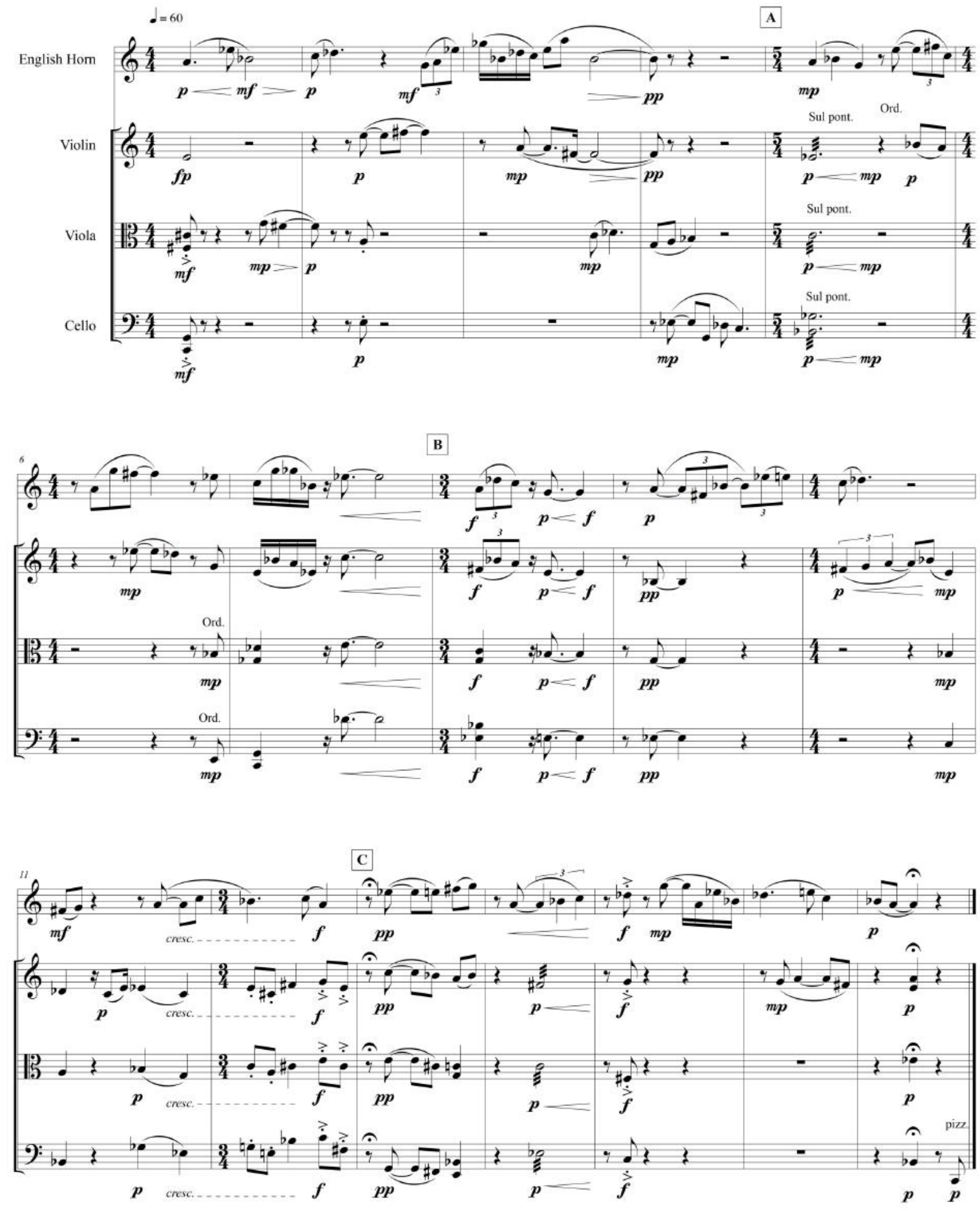


\section{APÊNDICE 2 - Oscilador Van der Pol}

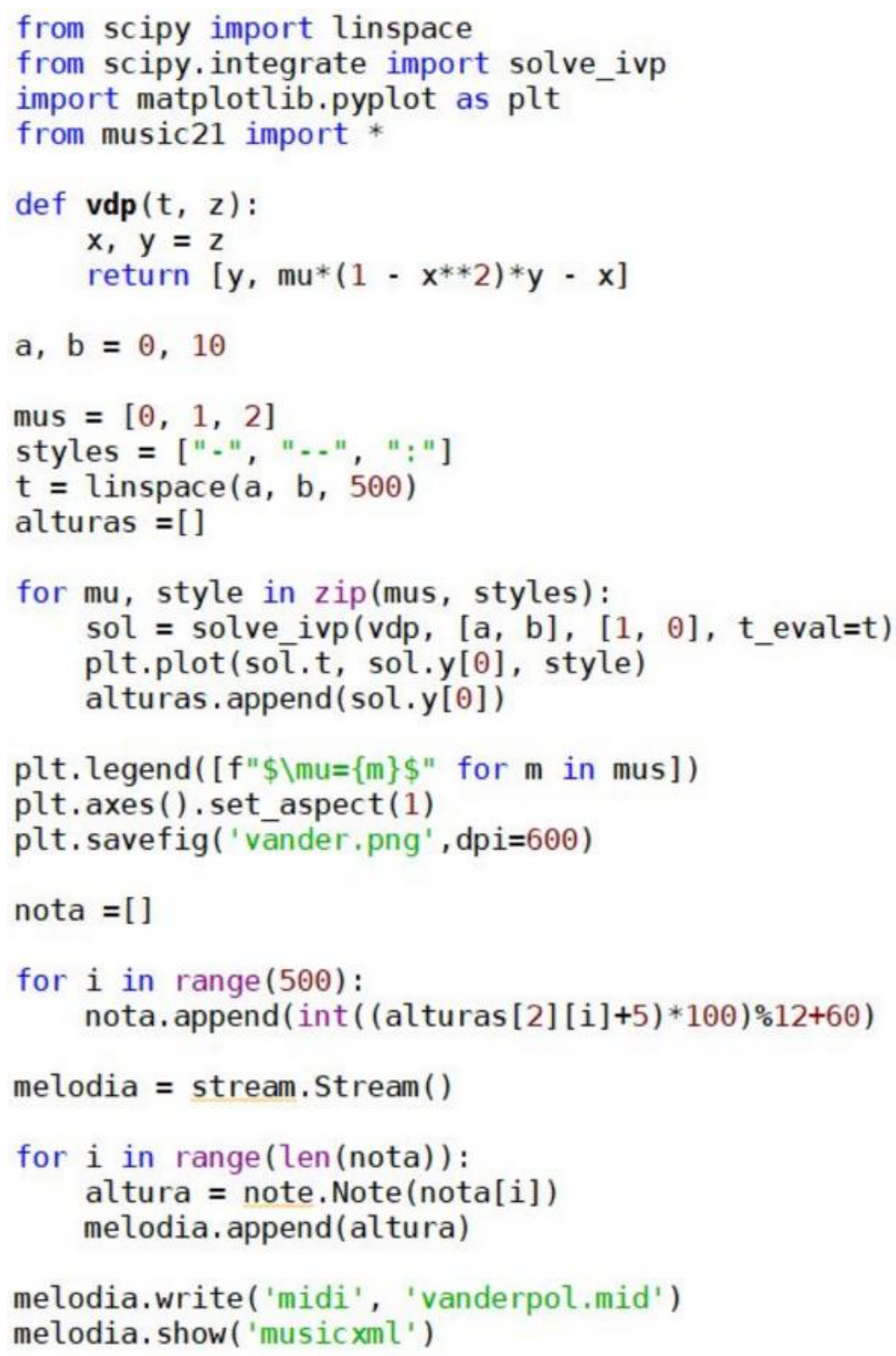




\section{APÊNDICE 3 - Trio produzido com o Oscilador Van der Pol}
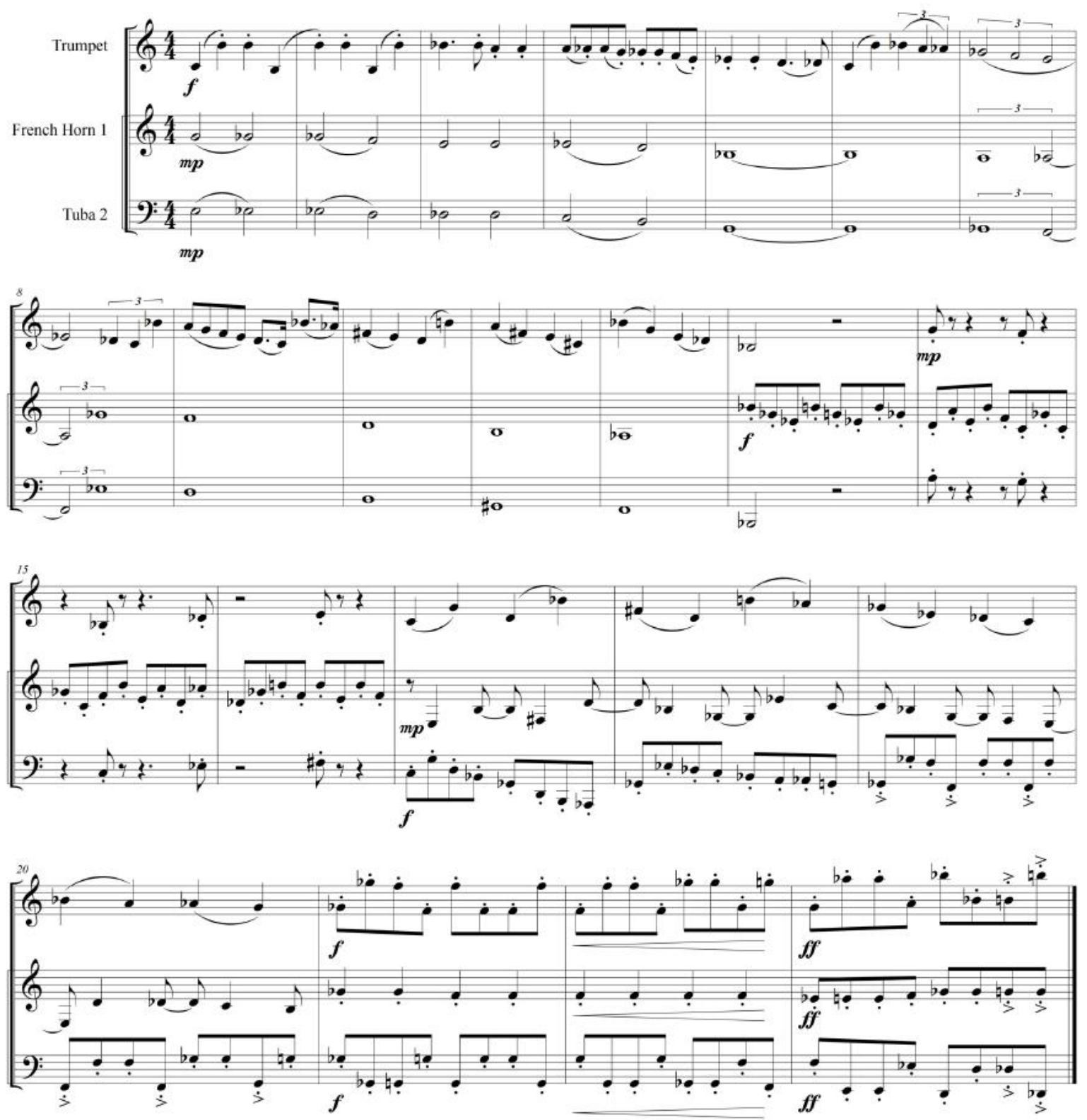